\title{
Costabili Palace and the Architecture "All'Antica" in Ferrara at the End of the XV Century
}

\author{
By Benedetta Caglioti
}

\begin{abstract}
Costabili Palace, also known as Ludovico "il Moro" (Ludovico Sforza, Duke of Milan) Palace, is located in Ferrara on the ancient Ghiara road, occupying the corner that it forms with via Porta d'Amore, in the south-eastern area of the city. Attributed to the architect Biagio Rossetti (1447-1516) it represents, by size and formal wealth, begun but never completed, the most ambitious palace of the Renaissance in Ferrara. Commissioned by Count Antonio Costabili (14501527) at the end of the Fifteenth century, the construction was interrupted in 1503. Of four sides of its court only two were built in their rich and cultured architectural language, and only half of the main façade was sketched. Through the unpublished archival research carried out, crossed with the direct study of the building by surveying the relevant stylistic elements, helped by a proportional analysis and the reading of the stratigraphic masonry units, this doctoral research retraces the history of the construction. This work has clarified the role of the artists involved and their relationship with the strong personality of the client Antonio Costabili, ambassador in Milan of the Duke of Ferrara (Ercole I d'Este) from the year 1496 until the year 1499, one of the most representative intellectuals of his time thanks to a solid humanistic and artistic education. From a systematic study of an unfinished building site the precise design of the Costabili Palace will emerge as expression of a clear linguistic and lexical intention, called "all'antica", inspired to the Roman classical architecture. The proposed research is wondering about the real contribution that the architectural culture in Ferrara at the end of the Fifteenth century, highly represented by the Costabili Palace, offers to the broader context of the Renaissance courts.
\end{abstract}

\section{Introduction}

Palazzo Costabili is located in south-eastern Ferrara, along the historic Via della Ghiara, now Via XX Settembre. The palace marks the intersection with Via Porta d'Amore, in the oldest part of the city, known as the Polesine di Sant'Antonio. The area is part of the expansion commissioned by Duke Borso d'Este (1450-1471) to create a street marking the historic and straight passage of the Po River, from east to west (Figure 1).

The palace continues to occupy a marginal position with respect to the historic centre of Ferrara, despite its imposing mass and architectural beauty. Far from the city's important religious centre, marked by the Cathedral, its position at the edge of the medieval city is also distant from the addition (known as Erculean Addition) to the city realised by Duke Ercole I d'Este (1471-1505) at the end of the fifteenth century, while Palazzo Costabili was under construction.

\footnotetext{
*PhD Student, Sapienza University of Rome, Italy.
} 
Figure 1. Identification of Costabili Palace (Red Circle) inside the City of Ferrara

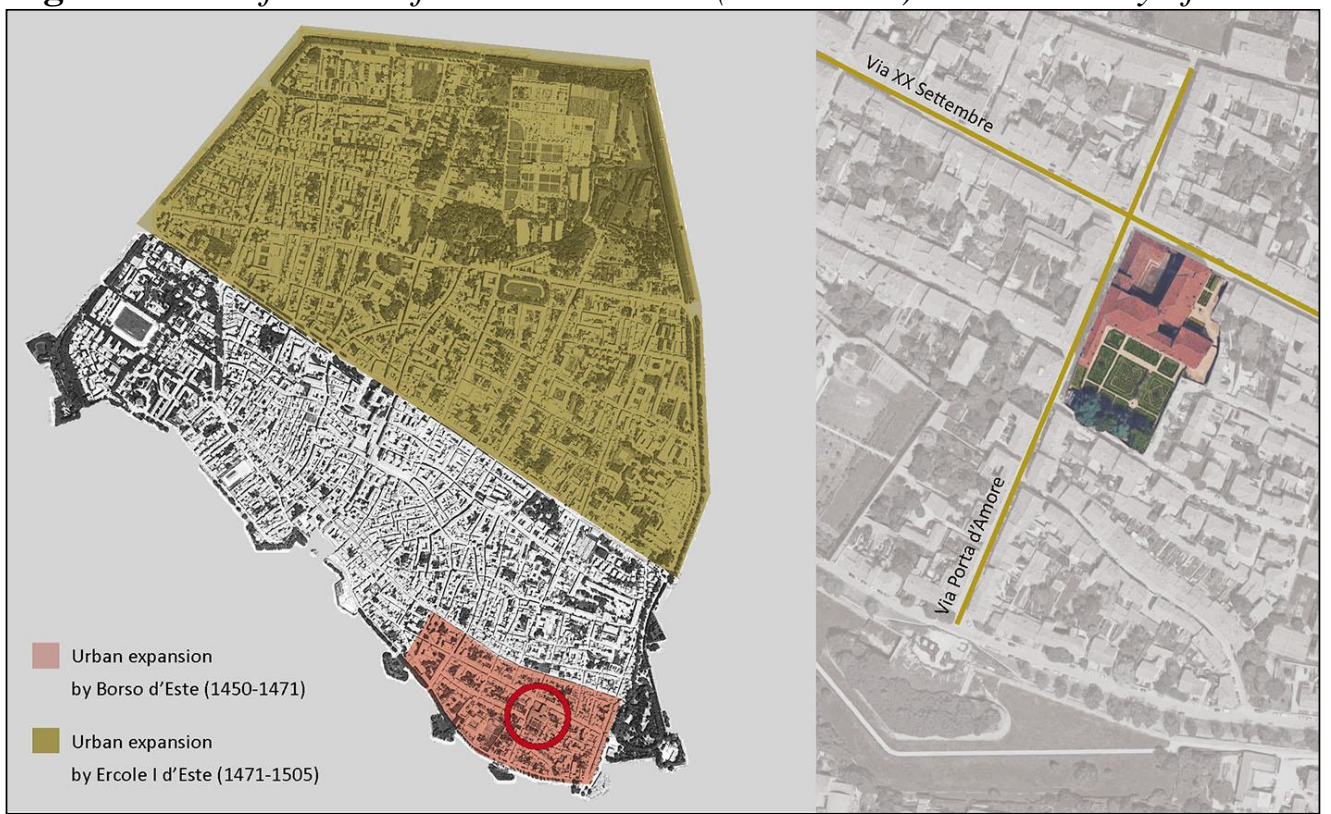

and the Great Urban Expansions of the City during the XV Century

Source: Elaboration of Satellite Images by the Author.

In Figures 2-4 the surveys and photomaps, taken by the author, are reported in order to understand the architecture of Palazzo Costabili.

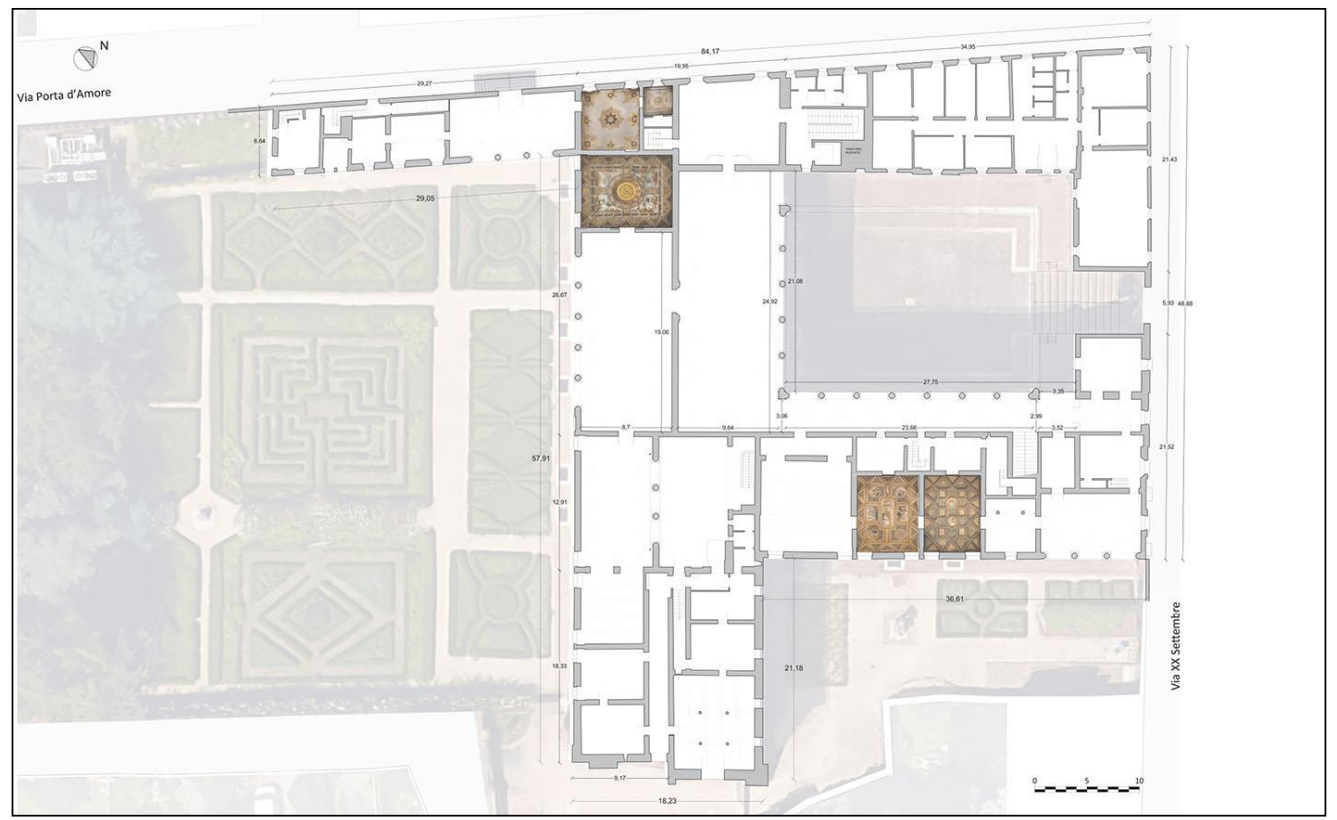

Figure 2. Ground Floor of the Palace

Source: Author. 


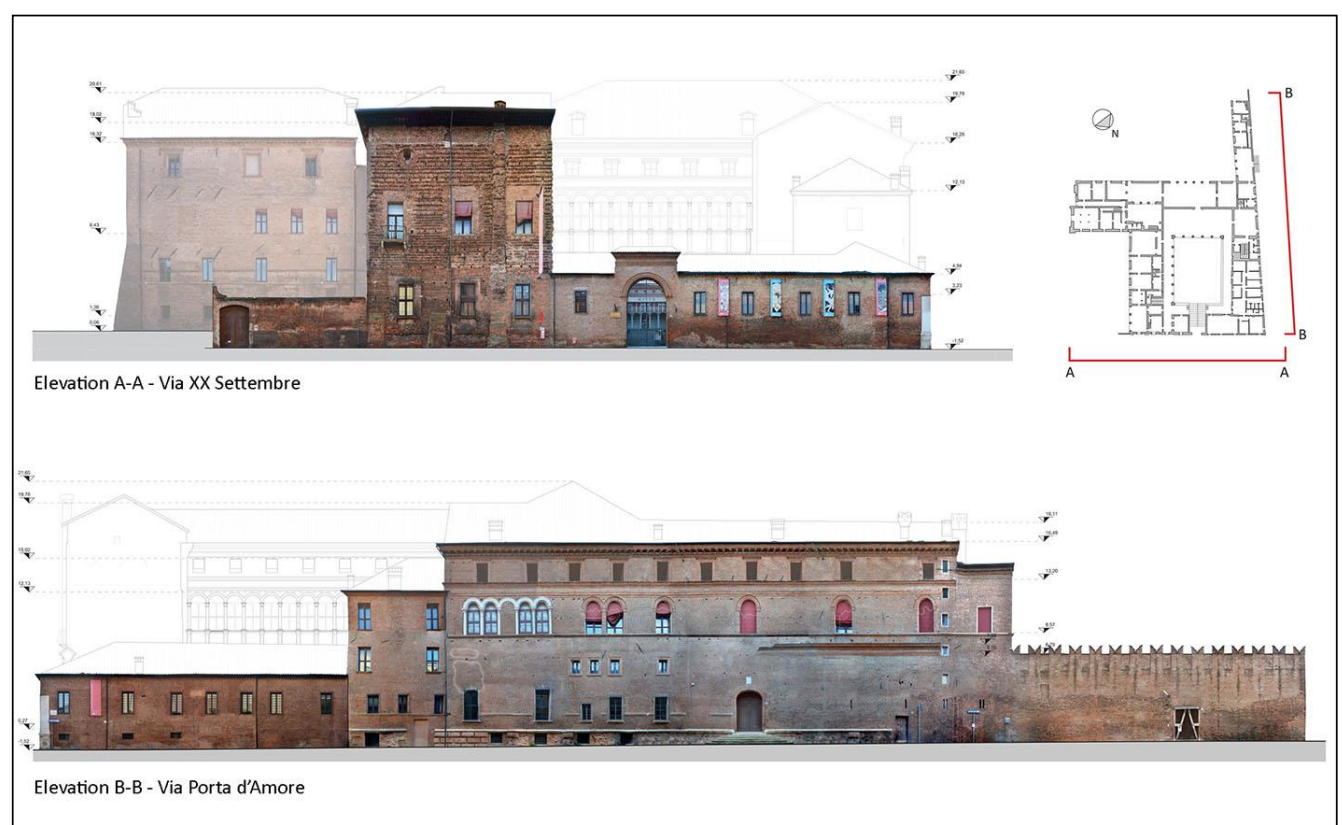

Figure 3. North and West Elevation of the Palace

Source: Author.

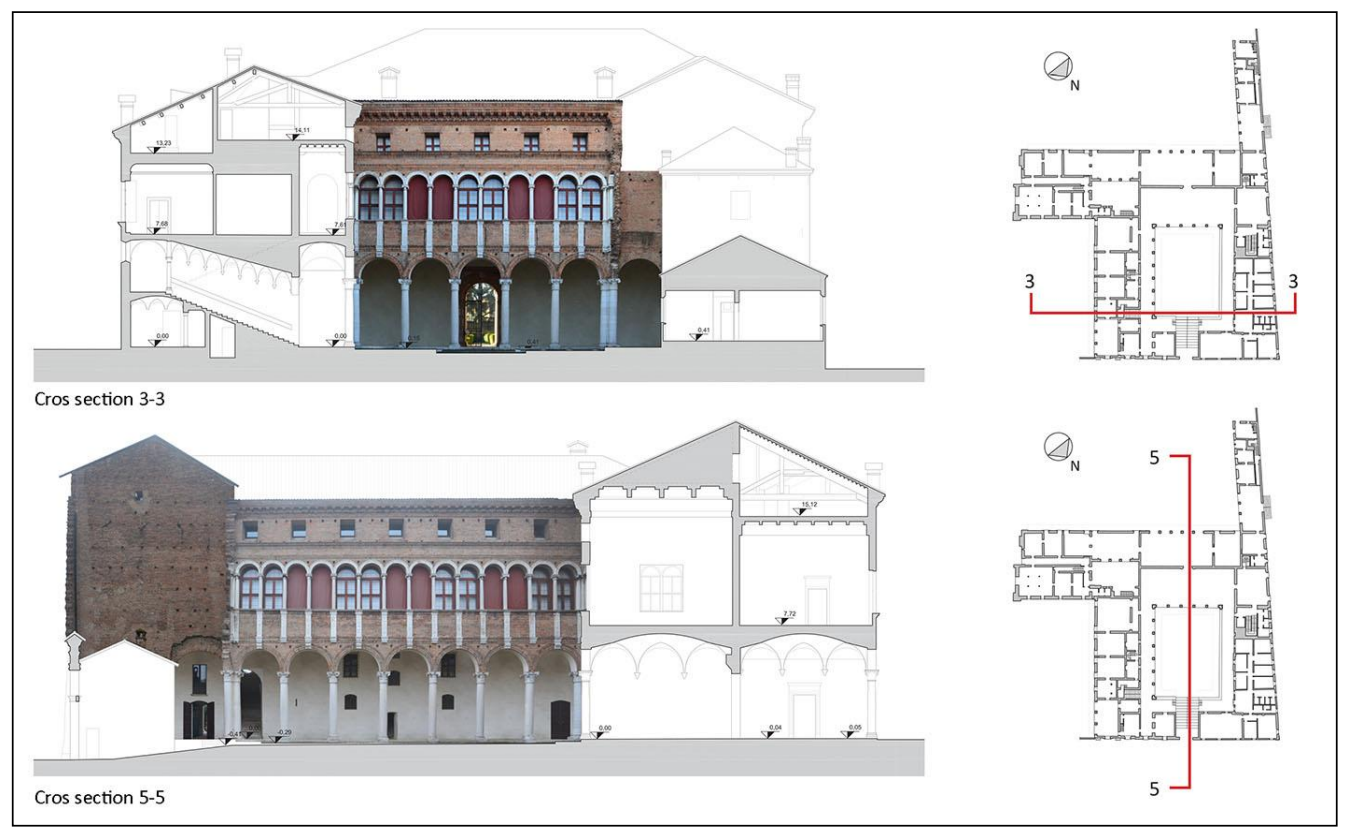

Figure 4. East and South Elevation of the Courtyard Source: Author.

A literature review and methodology assessment generated the decision to divide the discussion into four subsections. The first looks at the life of Antonio Costabili (mid-1400s-1527) in the context of late fifteenth-early sixteenth century Ferrara, using important unpublished letters from the State Archives in Milan and Modena describing a high profile cultural and political figure. 
The second subsection begins with an urban analysis of the site selected for the palace and continues with a study of its construction during the fifteenthsixteenth centuries using indirect and direct sources.

The third subsection explores the history of renovations to the palace, with a particular focus on the work carried out between 1932 and 1935. This renovation is presented for the first time based on an ordering of historic documents conserved in the archives of Ministry of Cultural Heritage of Ravenna, Ferrara and Rome. Drawings and photographs from before and after the restoration were analysed and overlapped with the current situation. A reading of this material revealed the extent of demolitions to the sixteenth century palazzo during the 1930s restoration works, and to what degree the building we observe today is the result of the interpretation of the Renaissance typical of those years.

The fourth subsection looks at the new language of antiquity adopted in latefifteenth century in Ferrara and the attribution of the design of the palace.

\section{Literature Review}

A survey of past studies exposed the lack of a unified and organic reading of a building defined "magnificis aedibus" by Celio Calcagnini, ${ }^{1}$ with a courtyard described by Burckhardt ${ }^{2}$ (1860) as "worth ten palaces, despite being only halffinished". The palace occupies an important position in the history of Renaissance architecture as the result of an encounter between various Italian schools, at a time of transition that would give birth to the unified architecture of the sixteenth century, as Giovannoni ${ }^{3}$ (1936) writes.

Guarini $^{4}$ (1621) was the first to propose Ludovico Sforza as the client of the palace in Ferrara. This tradition was taken up by Scalabrini ${ }^{5}$ (1773), Frizzi $^{6}$ (1787), Avventi $^{7}$ (1838), Agnelli $^{8}$ (1902) and Alfieri ${ }^{9}$ (1955). Padovani ${ }^{10}$ (1930) was the first to question this legend, citing the absence of any documentary proof and fundamental archival material from 1502 to 1503 explicitly listing Antonio Costabili as the client. However, in 1955 Padovani ${ }^{11}$ himself claimed that the possible dating of the start of construction made it impossible to categorically

1. C. Calcagnini, Opera Aliquot (Basilea, 1544), 436.

2. J. Burckhardt, Storia del Rinascimento in Italia (Torino: N. Aragno, 2006), 324.

3. G. Giovannoni, "Ferrara. The Palace of Ludovico il Moro," in Rassegna di Architettura, no. 8-9 (Milano: Graphic Institute, 1936), XXIV-XXVI.

4. M. A. Guarini, Compendio Historico dell'Origine, Accrescimento e Prerogative delle Chiese, e Luoghi pii della Città e Diocesi di Ferrara (Ferrara, 1621), 294-295. 288-289.

5. G. A. Scalabrini, Momorie Istoriche delle Chiese di Ferrara e de' Borghi (Ferrara, 1773),

6. A. Frizzi, Guida del Forestiere per la Città di Ferrara del Dott (Ferrara, 1787), 135-136.

7. F. Avventi, Il Servitore di Piazza: Guida per Ferrara (Ferrara: Pomatelli, 1883), 153-155.

8. G. Agnelli, Il Palazzo di Lodovico il Moro in Ferrara (Ferrara: Zuffi, 1902).

9. N. Alfieri, Il Palazzo Detto di Ludovico il Moro (Rovigo: STER, 1955).

10. G. Padovani, "Biagio Rossetti e il Palazzo di Antonio Costabili," in Corriere Padano (Ferrara: Soc. An. Emiliana, 1930).

11. Padovani, Architetti Ferraresi (Rovigo: STER, 1955), 82. 
exclude Sforza. Marcianò ${ }^{12}$ (1991) admits the hypothesis of a direct commission by Sforza citing a letter from 1493 in which the Milanese duke, struck by the beauty of the Duke of Ferrara's country villa known as Belriguardo, declares his desire to construct a residence in Ferrara.

The writings of Varese ${ }^{13}$ (1973) began to shed light on Antonio Costabili's importance at the court of Ferrara and affirm the idea that the Ferrarese count could have been the client who commissioned the palace. This hypothesis was taken up by Pattanaro ${ }^{14}$ (1994) and reinforced in the studies of Fidozzi and Guelfi ${ }^{15}$ (2007), who noted that the city's ruling class, to which Costabili belonged with full title, was as capable of producing high quality artistic works as the dukes.

The writings of Cittadella ${ }^{16}$ (1844) proved fundamental to understanding the history of the palace's construction. Together with the publication of archival documents from 1502 to 1503 , they provide certain dating for a construction site that was already underway by this time. The work of Calzecchi Onesti ${ }^{17}$ (1936) made it possible to hypothesise the chronological phases of construction. Padovani (1955) places the beginning works between 1495 and 1498 if the client was the Milanese duke, or 1499-1500 if this role is instead to be attributed to Antonio Costabili. Pattanaro (1994) provides unpublished archival evidence of a testimonial ${ }^{18}$ from 1507 in which the palace is presented as still in fieri.

A decisive understanding of the history of the palace's construction came with the robust publication by Adriano Franceschini, ${ }^{19}$ to whom we owe the transcription of almost all of the documents conserved in diverse Archives relative to the artists present in Ferrara between 1341 and 1516. In particular, the volumes relative to the years 1472-1492 and 1493-1516, published between 1995 and 1997, continue to be a source of important discoveries for historians. The documents provided by Franceschini permitted Baretta ${ }^{20}$ (1998) to offer a more precise history of the palace's construction during the final years of the fifteenth century and the early years of the sixteenth century.

12. A. F. Marcianò, L'Età di Biagio Rossetti. Rinascimenti di Casa d'Este (Ferrara-Roma: Gabriele Corbo Editore, 1991), 115-126.

13. R. Varese, "Il Palazzo di Costabili (Detto di Ludovico il Moro,)" in Spina. Museo Archeologico Nazionale di Ferrara (Bologna: Calderini, I-XXV).

14. A. Pattanaro, "Garafolo e Cesariano in Palazzo Costabili a Ferrara," in Prospettiva (Firenze: Centro Di, 1994), 97-110.

15. I. Fedozzi and B. Guelfi, "Nuovi Documenti e Ipotesi di Lavoro su un Committente Ferrarese nell'Età di Alfonso I: il Conte Costabili," in Il Camerino delle pitture di Alfonso (Padova: Bertoncello Arti Grafiche, 2007), 65-76.

16. N. Cittadella, Indice Manuale delle Cose Più Rimarcabili in Pittura, Scultura, Architettura della Città e Borhi di Ferrara (Ferrara, 1844), 67-69.

17. C. Calzecchi Onesti, "Il Palazzo detto di Lodovico il Moro, Cenni Storici e Critici e Relazione sui Restauri," in The Spina Museum in Ferrara (ed.) S. Aurigemma (Ferrara: Municipality of Ferrara, 1936).

18. Pattanaro, Garafolo e Cesariano in Palazzo Costabili a Ferrara, 1994, 98.

19. A. Franceschini, Artisti a Ferrara in Età Umanistica e Rinascimentale. Testimonianze Archivistiche (Ferrara-Roma: Gabriele Corbo Editore, 1997).

20. S. Baretta, "Il Palazzo di Ludovico il Moro," in F. D. Bollettino della Ferrariae Decus (Ferrara: Este Edition, 1998), 7-22. 
Regarding the history of renovations, the works carried out between 1932 and 1936 drew harsh criticism from Alfieri (1955), Zevi ${ }^{21}$ (1960), Di Francesco ${ }^{22}$ (1996) and Sambin $^{23}$ (2018) for the choice to demolish the walls closing two bays of the colonnade, every two bays, on the second order of the internal courtyard following their presumed attribution to Donato Bramante.

The attribution of the design of Palazzo Costabili was initiated by Cittadella (1844). Using archival material from 1502 and 1503, he was the first to place the architect Biagio Rossetti and the stone mason Gabriele Frisoni on site. Successively, diverse scholars, such as Agnelli (1902 and 1909), Reggiani ${ }^{24}$ (1907) and Righini ${ }^{25}$ (1911) accepted Rossetti as the designer, citing both these documents and stylistic analogies with other coeval buildings attributed to the architect.

In 1914 Righini, ${ }^{26}$ followed by Boari, ${ }^{27}$ despite the certainty only a few years earlier of Rossetti's role, claimed that Palazzo Costabili was instead designed by Donato Bramante, and that Rossetti was a "contractor" or "builder". This affirmation arises from the recognition at Palazzo Costabili of the particular composition, above the entire internal courtyard, typical of the architecture of Donato Bramante and far from the language of Rossetti, incapable of such refined decoration. Also in 1914, criticisms were raised against this attribution by both Reggiani $^{28}$ and Zaccarini. ${ }^{29}$

The work of Padovani (1930) and Calzecchi Onesti (1936) introduced the first distinction between the language of composition and the construction of the palace itself from that of the courtyard: while for the former the references were to coeval architecture in Ferrara, the latter instead looked to models outside the city. Successively, in 1955, while reaffirming the total attribution to Rossetti, Padovani nonetheless emphasised the distinction between the architecture of the volumes of the palace and the composition of the courtyard.

A determinant contribution was made by Bruno Zevi (1960), who attributed the design of the palace exclusively to Rossetti for both its formal characteristics

21. B. Zevi, Biagio Rossetti Architetto Ferrarese il Primo Urbanista Moderno Europeo (Torino: Einaudi, 1960), 320-324.

22. C. Di Francesco, "Palazzo di Ludovico il Moro (Note Storiche,)" in Giardini e Palazzi Rinascimentali di Ferrara. Sviluppo Urbanistico Moderno (Ferrara: Atti del Corso di Aggiornamento, 1996), 194-199.

23. M. T. Sambin de Norcen, "Osservazioni sui Palazzi (1490-1503,)" in Grande così Quanto Forse Ignorato: Omaggio a Biagio Rossetti (Ferrara: Grafiche Turato Edizioni, 2018), 49-66.

24. G. Reggiani, I Portali di Ferrara nell'Arte (Ferrara: Tipografia Taddei-Soati, 1907), 102-103.

25. E. Righini, Quel che Resta di Ferrara Antica (Ferrara: Estense Libro, 1911), 55-98.

26. Righini, "Bramante, Rossetti e il Palazzo d Ludovico il Moro," in Gazzetta Ferrarese (Ferrara: Officina della Gazzetta, 1914).

27. A. Boari, "Bramante, Rossetti e il Palazzo d Ludovico il Moro Bramante," in Gazzetta Ferrarese (Ferrara: Officina della Gazzetta, 1914).

28. Reggiani, "Bramante, Rossetti e il Palazzo d Ludovico il Moro," in Gazzetta Ferrarese (Ferrara: Officina della Gazzetta, 1914).

29. D. Zaccarini, "Ferrara. Palazzo di Ludovico il Moro," in Architettura e arti decorative Ferrara (Milano-Roma: Bestetti and Tumminelli, 1922), 304-305. 
and its composition considered typical traits of Ferrarese architecture. In the wake of Zevi's important work, Rossetti's authorship was also accepted by Piconi Aprato $^{30}$ (1972), Varese ${ }^{31}$ (1979), Marcianò (1991) and Di Francesco (1996); Pattanaro $^{32}$ (2009 and 2018) and more recently by Sambin De Norcen ${ }^{33}$ (2018) through analogies with Belriguardo, and for a language distant from the reference to antiquity matured by Bramante as early as the late fifteenth century.

\section{Methodology}

The methodology ${ }^{34}$ utilised in the study of Palazzo Costabili, after examining the level of existing studies and looking at issues yet to be explored, overlays results provided by direct and indirect sources.

The former were catalogued for bibliographic, archival, iconographic and cartographic research. A chronological register allowed for the identification of certain dates, contradictions, temporal gaps and differing interpretations of the history of the palace's construction.

Direct sources consist of an architectural survey, enriched by additional sections, plans and details, a typological survey and a photogrammetric mapping of the elevations and vault decorations. Direct analysis was used to investigate the building's different construction systems, from the foundations to the roof. This process identified anomalies, alignments, the opening and/or closure of doors and windows, surveyed and catalogued based on differentiations in materials and dimensions, and traces of interruptions and discontinuities in masonry work. An editable version of this survey was used to analyse measurements and proportions by converting actual measurements into Ferrarese feet (equivalent to $0.4039 \mathrm{~m}$ ).

\section{Discussion (together with findings and results)}

\section{The Client: Antonio Costabili}

It is likely that Antonio Costabili ${ }^{35}$ was born in Ferrara in the early second half of the fifteenth century and that he received a military and humanist education.

30. G. Piconi Aprato, "Il Palazzo Detto di Lodovico il Moro in Ferrara," in Ferrarese Museums, Annual Bulletin (Firenze: Centro Di, 1972), 117-128.

31. Varese, "Il Palazzo di Costabili (Detto di Ludovico il Moro,)" In Spina. Museo archeologico nazionale di Ferrara, 1973, I-XXV.

32. A. Pattanaro, "Il Restauro di un Importante Affresco Rinascimentale Apre Nuove Prospettive Storiche," in Ferrara voci di una città (Ferrara: Cassa di Risparmio di Ferrara Foundation, 2009), 39-43.

33. Sambin de Norcen, Osservazioni sui Palazzi (1490-1503), 2018, 49-66.

34. A. Bruschi, Introduzione alla Storia dell'Architettura. Considerazioni sul Metodo e sulla Storia degli Studi (Città di Castello: Mondadori Università. 2009).

35. F. Petrucci, "Antonio Costabili," in Biographical Dictionary of Italians (Roma: Institute of the Italian Encyclopedia, 1984), 257-260. 
His military valour earned him the title of Savour of the State from the Duke. After serving in the military, Costabili moved on to a diplomatic career. He served as ambassador in Milan under Duke Ludovico Sforza (1494-1499) from 1496 to 1499. Costabili's service under Duke Sforza earned him the title of "Familiare" and "Consigliere di Ludovico". He had the privilege of accompanying il Moro to meetings with the Holy Roman Emperor Maximilian I in Tirano and Bormio. In 1498, Maximilian I personally afforded Costabili the privilege of using the black eagle in a field of gold on his personal coat of arms. This herald would later appear on the piano nobile of his palace, on the wood beams of the soffit in two rooms and in the hallway leading from the grand staircase to the main hall (Figure 5).

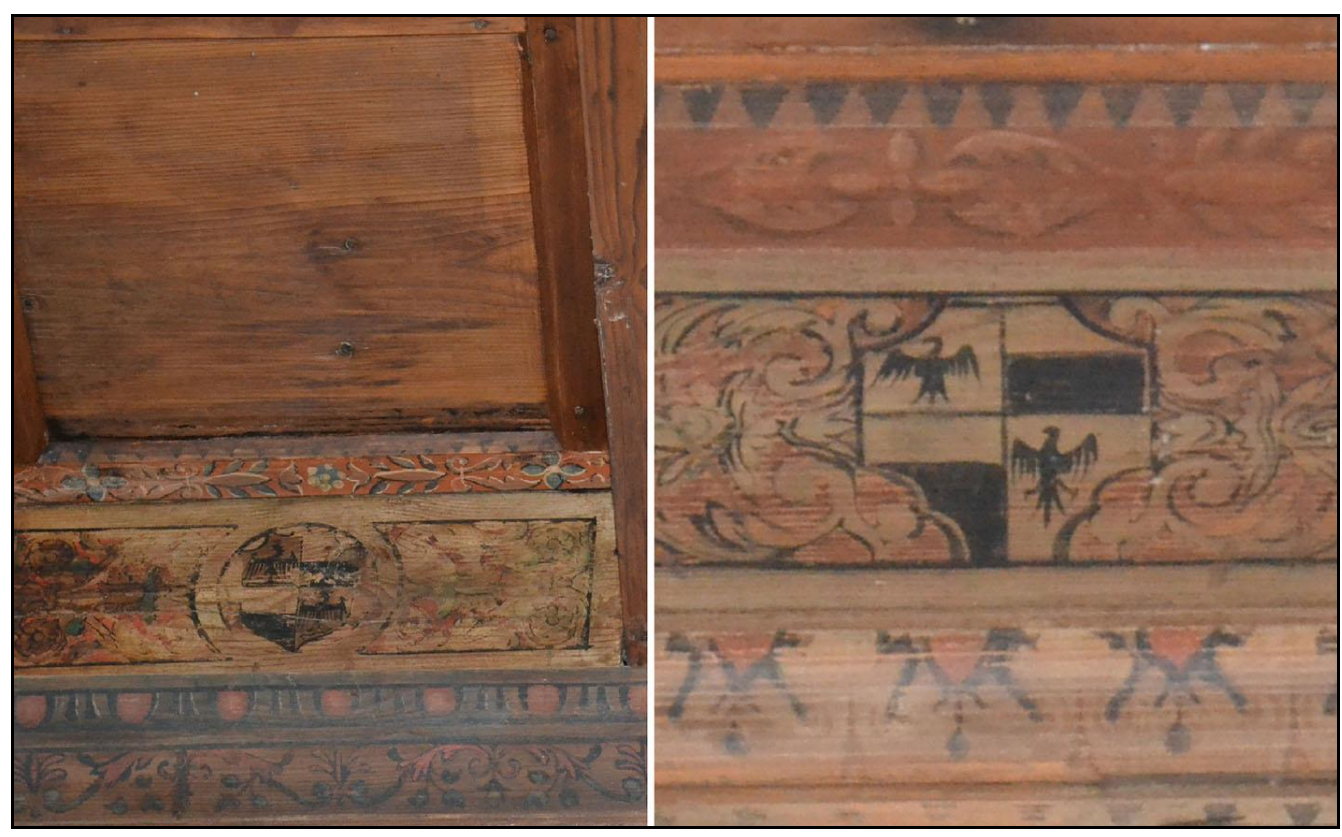

Figure 5. Personal Coat of Arms of Antonio Costabili

Source: Photographs by the Author.

Many of the letters written after 1496 by Costabili to Duke Ercole I d'Este are conserved at the State Archives in Milan. In these letters, the ambassador exercises his role as a key figure in deciding the fate of the Duchy of Ferrara and Milan, within the vaster web of relations and expansionist designs of the kings of France, Spain, Germany and Great Britain, and the Pope with them. The historicalpolitical context in which Antonio Costabili operated as ambassador during the 1490s was crucial to the fragile equilibrium of Italy's various courts, in the climate of pacific accord reached between states with the Peace of Lodi in 1454.

Costabili accompanied Ludovico Sforza until 1499, the year Louis XII, King of France, conquered the Duchy of Milan.

Upon returning to the Duchy of Ferrara, Costabili received important public commissions.

The variety of situations that emerges from a reading of unpublished material conserved at the State Archives in Modena relative to Costabili's return to Ferrara demonstrates a capacity to respond to the accidental development of events with temperance and resolve. The documents describe a multifaceted personality and a 
talent for responding to the most delicate expectations of the Duke regarding the management of possible problems faced by the city (for example to guarantee public order, to control the work site of the new city walls and to manage the emergency of the plague).

The capacity to observe, evaluate and even modify an order while it was being carried out, with total transparency and loyalty to the Duke, and with an equally lively freedom of judgment, made Costabili a figure the Duke could turn to with extreme familiarity and trust. A man equally able to deal with questions of public order, unafraid to send armed troops ${ }^{36}$ when necessary, as well as the most private questions; for example celebrating to Duke Alfonso I the virtues of his wife, the Duchess Lucrezia Borgia, and the healthy growth of their son Ercole. Costabili's many letters, the last, about the plague in Ferrara, dated June 12, 1527, two months prior to his death, paint the portrait of a man devoted to his Duke, his city and its citizens.

As mentioned, Antonio Costabili was also linked to the delicate international political questions that arose in the late fifteenth and early sixteenth centuries. On more than once occasion his role proved decisive and his friendships made him indispensable to the d'Este Dukes, initially Ercole I, and Alfonso I after him. The descendent of a prestigious family, which had already occupied important public positions, Antonio established an even denser network of political, as well as cultural exchanges, no doubt with Milan, thanks to his time there as the Sforza's ambassador, but also in Rome, thanks to his close relations with his brother Beltrando, ambassador to the Roman Curia.

A fundamental part of this study is the development of an entirely new understanding of Antonio Costabili within the humanist culture of the Ferrara court in the fifteenth and sixteenth centuries. What emerges is a figure of impressive cultural depth, perfectly inserted within the humanist climate that already permeated the court since the first half of the 1400s.

The programme of frescoes desired by Costabili for his palace under construction reveals to what degree the literary and figurative culture of its client reflected a frequentation, a habit of familiarity with the most cultured protagonists of the Ferrara court, which welcomed the most sensible new artistic movements. From his education, Costabili shared the virtues of the circle of humanists, present at court in Ferrara. They substantiated the ethical values of antiquity, as demonstrated by Costabili's anything but casual choice of the poem Anteros sive de mutuo amore, by the humanist Celio Calcagnini, for his "Treasure Room", the most intimate and precious space in the palace (Figure 6).

36. State Archive in Modena, "Cancelleria Marchionale poi Ducale Estense," bag 7, letters of 3 July 1499, 23 August 1510, 25 May 1518. 


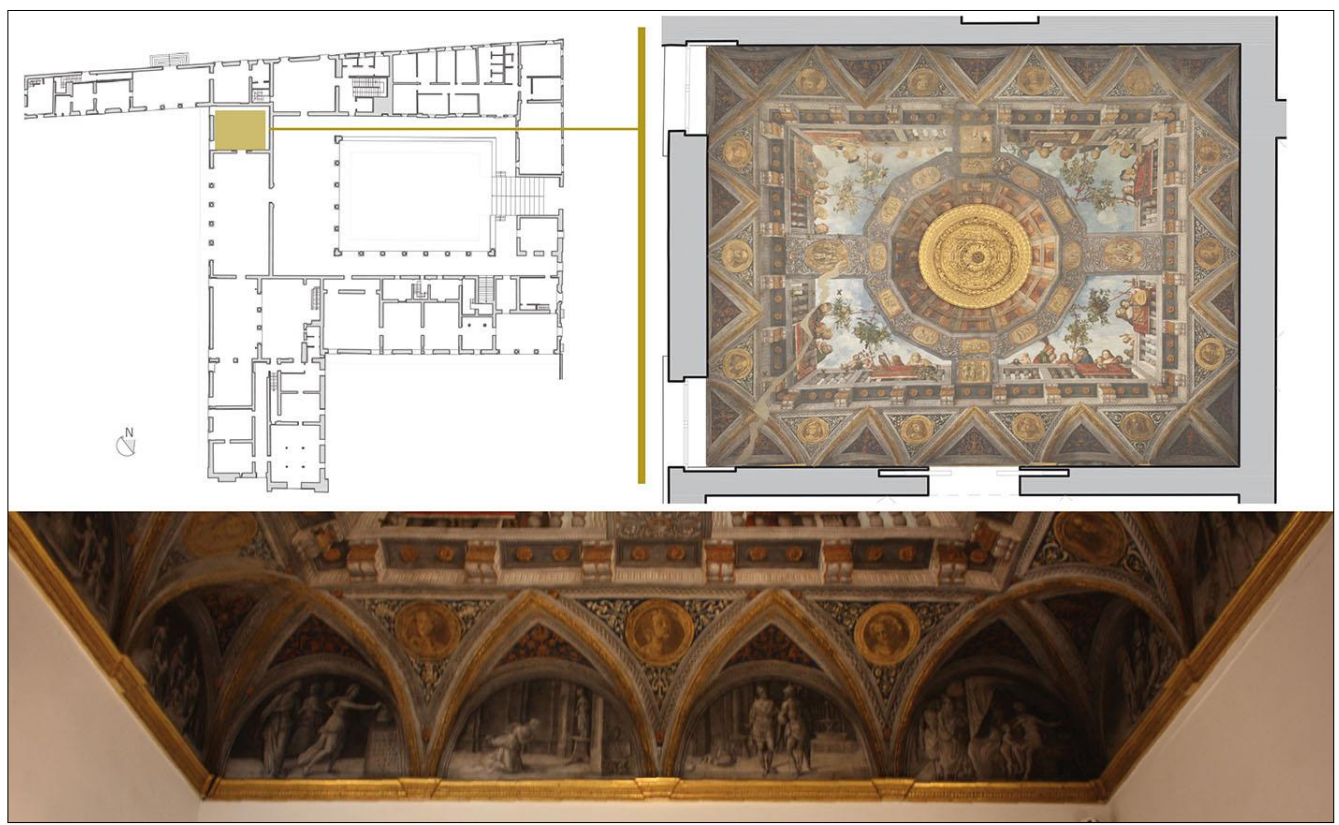

Figure 6. Identification of the "Treasure Room" in the Costabili Palace

Source: Survey, Photomap and Photograph by the author.

Costabili was familiar with the expressions of ancient literary culture and it was to these values that he dedicated the decorations of the rooms in his palace, reflecting the words written by Calcagnini in the introduction to his poem: "Your numerous commitments on behalf of citizens and the community should testify to your devotion and generosity: yet, as the Greeks thought, a man's mettle is understand through his words, you have advanced the idea of specific praise for you in your marvellous home where you exhibit your benevolence and your grateful attention through friendship."37

Exemplary for comprehending the importance of their reciprocal friendship, typical of an ancient humanist culture, is an unpublished letter ${ }^{38}$ from May 1496 found in the State Archives in Milan, in which Ercole I d'Este writes to Ludovico Sforza: "(...) We can be certain that your Excellence loves us, as you say, as our love is mutual and reciprocal (...)". For Costabili, the mutual love described by Calcagnini moved beyond the doors of the private room of a noble palace to take form in the words of a Duke in all of his power as a tool of government.

\section{The Erculean Addition and Antonio Costabili}

The phenomenon of urban expansion at the end of the fifteenth century, known as the Erculean Addition, commissioned by Ercole I, saw Ferrara grow in a manner never before conceived by political power. Its study aids an understanding of the relationship between Antonio Costabili and the city. It is also of interest to

37. The translation from the Latin was made by the author.

38. State Archive in Milan, Book 337, Letter of 16 May 1496. 
the relationship between the history of the Costabili family and political power reflected in the choice of the site of Antonio's palace.

The ancient city was far from the Erculean Addition. Its original nucleus was in an area to the south-east, known as the Polesine di Sant'Antonio, reclaimed less than fifty years earlier. This was the area in which Antonio Costabili chose to erect his palace.

It is important to note that Antonio's father, Rainaldo Costabili, served as a counsellor to Borso d'Este and Ercole I d'Este and possessed lands acquired in the area of Sant'Antonio in Polesine and properties in the Erculean Addition.

Antonio Costabili could thus choose the site for his palace from among two equally advantageous locations, as his father's possessions afforded him lands in either the old or the new city. The choice fell on the older part of Ferrara, where he proceeded to erect a palace of unprecedented dimensions on a narrow strip of land in the ancient city, a few dozen metres from the river. At the time, this area was home to three-storey constructions generally no wider than a few dozen metres. ${ }^{39}$ Other than being the oldest part of the city of Ferrara, the Polesine di Sant'Antonio was also home to the Costabili family, as we know from a document dated February 6, 1497. The same letter also speaks of the desire expressed by Antonio's brother, Beltrando Costabili, who boasted important commissions at the Cathedral of Ferrara, to build a home in the Polesine di San Antonio. The same area was already home to the Augustinian convent of Sant'Andrea, the burial place of the Costabili family, and whose high altar had been commissioned by Antonio Costabili himself.

\section{The History of the Palace's Construction}

Archival material offers evidence of land purchases in the Polesine di Sant'Antonio by Costabili on May 14, 1495, and another purchase the same year, though it was registered only in 1497.

Following these acquisitions, indirect sources show payments beginning in October 1495, and later in 1496, 1497 and at two moments in 1498, made by ducal bankers on behalf of Antonio Costabili. Given their dimensions, in particular those listed in the act from May 1495, these terrains are most likely those acquired for the construction of the palace. Indirect sources would seem to support a hypothesis of an intention to begin construction between 1495 and 1496.

The fact that Palazzo Costabili was built on pre-existing constructions is additionally confirmed by direct sources: an analysis of the thickness of the walls matches that of the row houses typical of the area of Sant'Antonio in Polesine. This same dimension was used to structure the south wing where it faces both the garden and the courtyard. This southern block was the first to be erected during an initial phase of construction datable to between 1496 and 1501 (Figure 7).

39. C. Nardelli, and M. Tassotti, L'Addizione di Borso: Analisi dell'Edilizia Storica sull'Asse Quattrocentesco di via Ghiara: Individuazione del Limite Fisiologico di Trasformazione degli Organismi Edilizi Finalizzata alla Loro Conservazione. Master's Degree Thesis (University of Ferrara, 2009). 


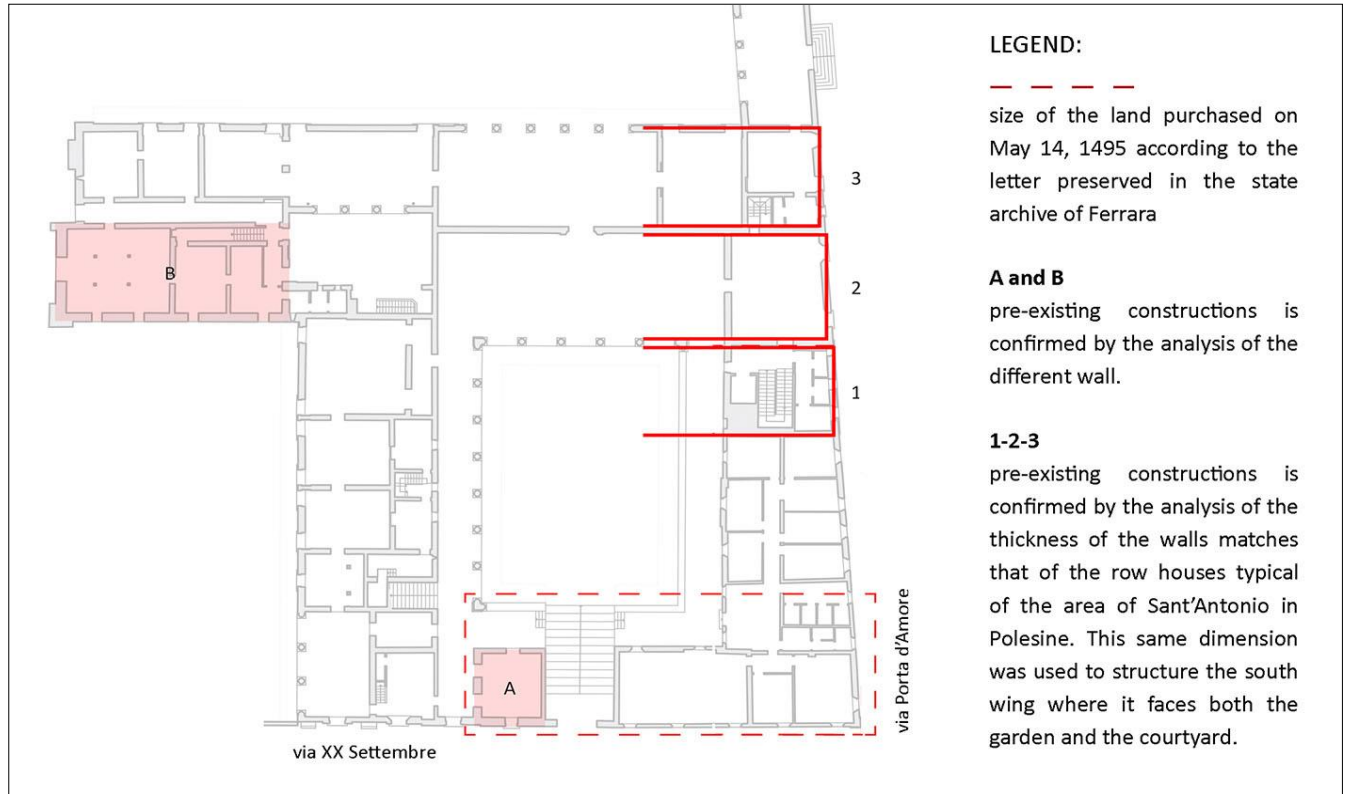

Figure 7. Identification of the Pre-Existing Constructions in the Costabili Palace through the Analysis of the Wall

Source: Survey by the Author.

Archival documents take us to 1501, when Maestro Antonio di Gregorio stone mason, a resident of the same quarter as Costabili, commits to supplying six columns and other works in marble. ${ }^{40}$ The six columns motioned in these documents are those of the two loggias facing the garden (Figure 8).

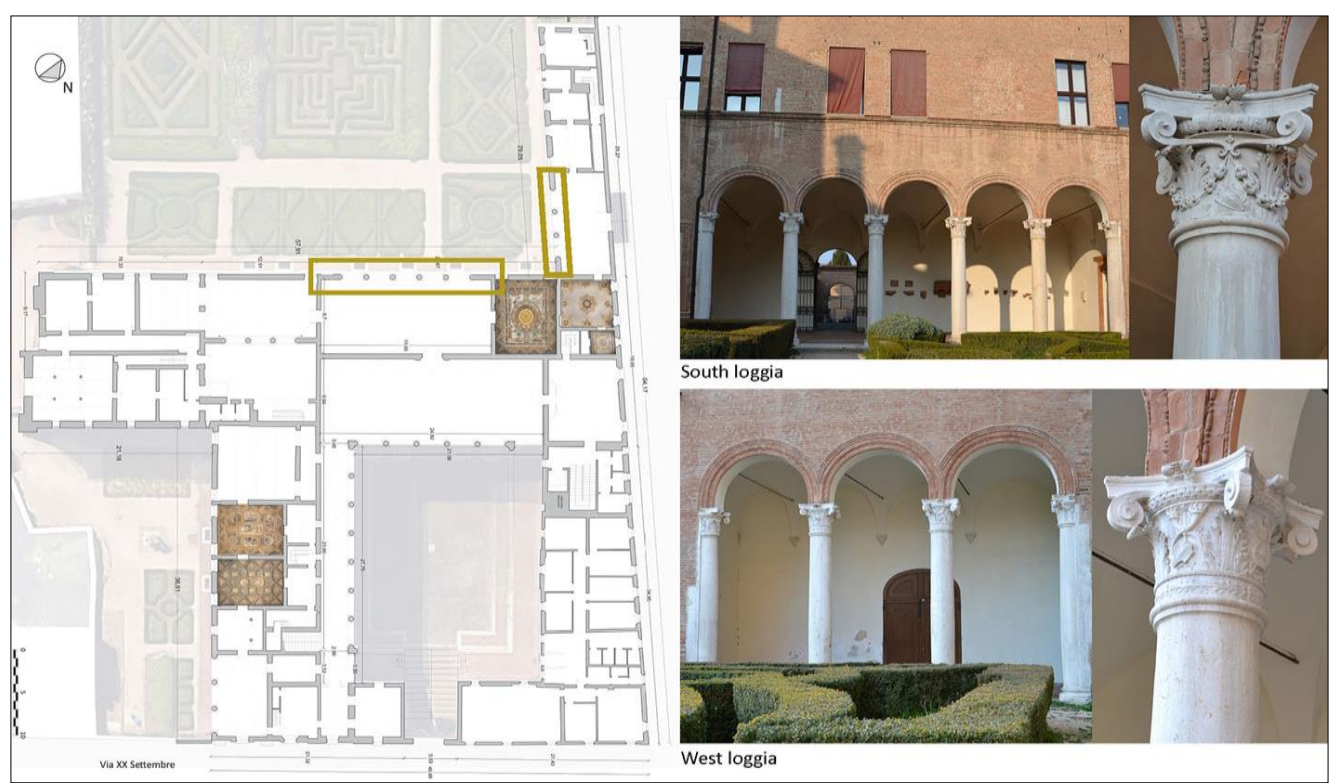

Figure 8. Identified to the Left on the Survey of the Ground Floor Are the Two Loggias towards the Garden (Identified with Yellow Boxes)

Source: Survey, Photomaps and Photographs by the Author.

40. Franceschini, Artisti a Ferrara in Età Umanistica e Rinascimentale. Testimonianze Archivistiche, 1997, 477. 
From this we can infer that by 1501 the south block of the palace, facing Via Porta d'Amore, as well as the garden, were under construction.

Archival sources list Antonio di Gregorio's death in $1502 .{ }^{41}$ This appears to be the most plausible explanation for the arrival on site of another stone mason: Gabriele Frisoni. Three documents from April $1502^{42}$ containing written acts with the Client Antonio Costabili, define diverse roles on site and relations between trades. Biagio Rossetti is listed as the guarantor for the mason Tristano and the stone mason Frisoni. It is important to note that, like Maestro Antonio di Gregorio, both Biagio Rossetti and the mason Tristano hail from the same quarter as Antonio Costabili.

However, one year later, in September $1503^{43}$ Biagio Rossetti and Frisoni, handed the works over to Maestro Girolamo Pasini "a smith" and Maestro Cristoforo, stone mason. A fundamental part of this document is its reference to a notarised act dated $1502^{44}$ and signed by Rossetti and Frisoni for all of the marble work necessary for Antonio Costabili's building site. All of the material listed as of April 1502 refers to the conclusion of three sides of the courtyard: east, west and north. The south side had already been defined.

However, one year later, in October $1504,{ }^{45}$ both Maestro Cristoforo da Milano and Maestro Girolamo Pasini resigned from their positions. From this moment onward, the archives contain no further documentation about the construction of the palace.

In terms of composition, direct analysis demonstrates that if the first limit on the realisation of the palace was represented by the pre-existing constructions along Via Porta d'Amore, the second was imposed by the pre-existence of the block to the south-east. At the time of construction of the eastern wing, begun in 1502, a connection was created: a "masonry bandage" can be observed in correspondence with the junction between the two blocks (Figure 9).

As work progressed in 1502, either more errors were made, or numerous variations were introduced. The first error takes the form of what appears to be a failed alignment between the corner column to the north-east of the internal courtyard and the entrance to the grand stair (Figure 10).

41. State Archive in Milan, "Camera Ducale Estense, Munizioni e Fabbriche," book 39, letter of 31 Dicember 1502.

42. Franceschini, Artisti a Ferrara in Età Umanistica e Rinascimentale. Testimonianze Archivistiche, 1997, 125.

43. Ivi, 431.

44. Ivi, 262.

45. Ivi, 481. 


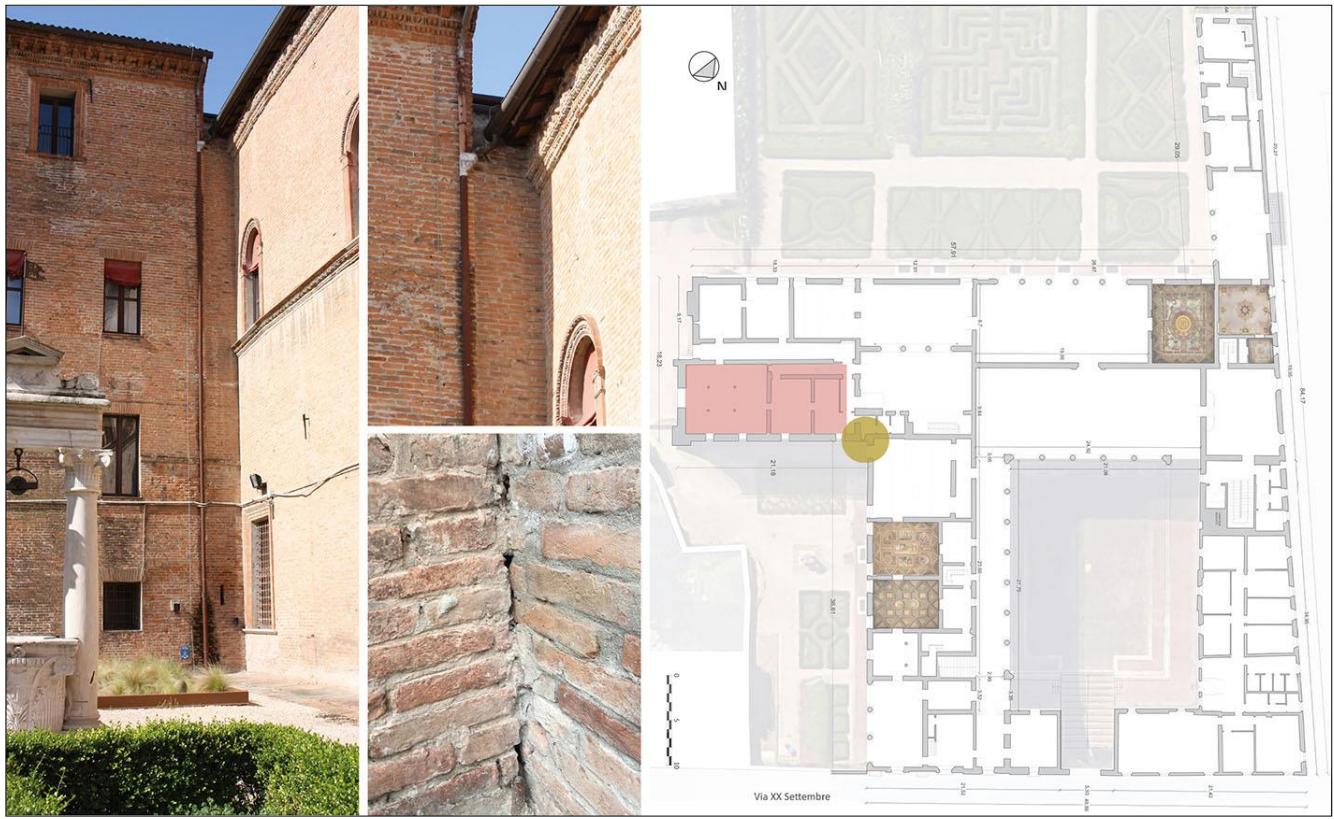

Figure 9. The "Masonry Bandage" (Identified with a Yellow Circle on the Plan) between the Pre-Existing Construction (in Red on the Plan) and the New Construction of Palazzo Costabili to the East

Source: Survey, Photomaps and Photographs by the Author.
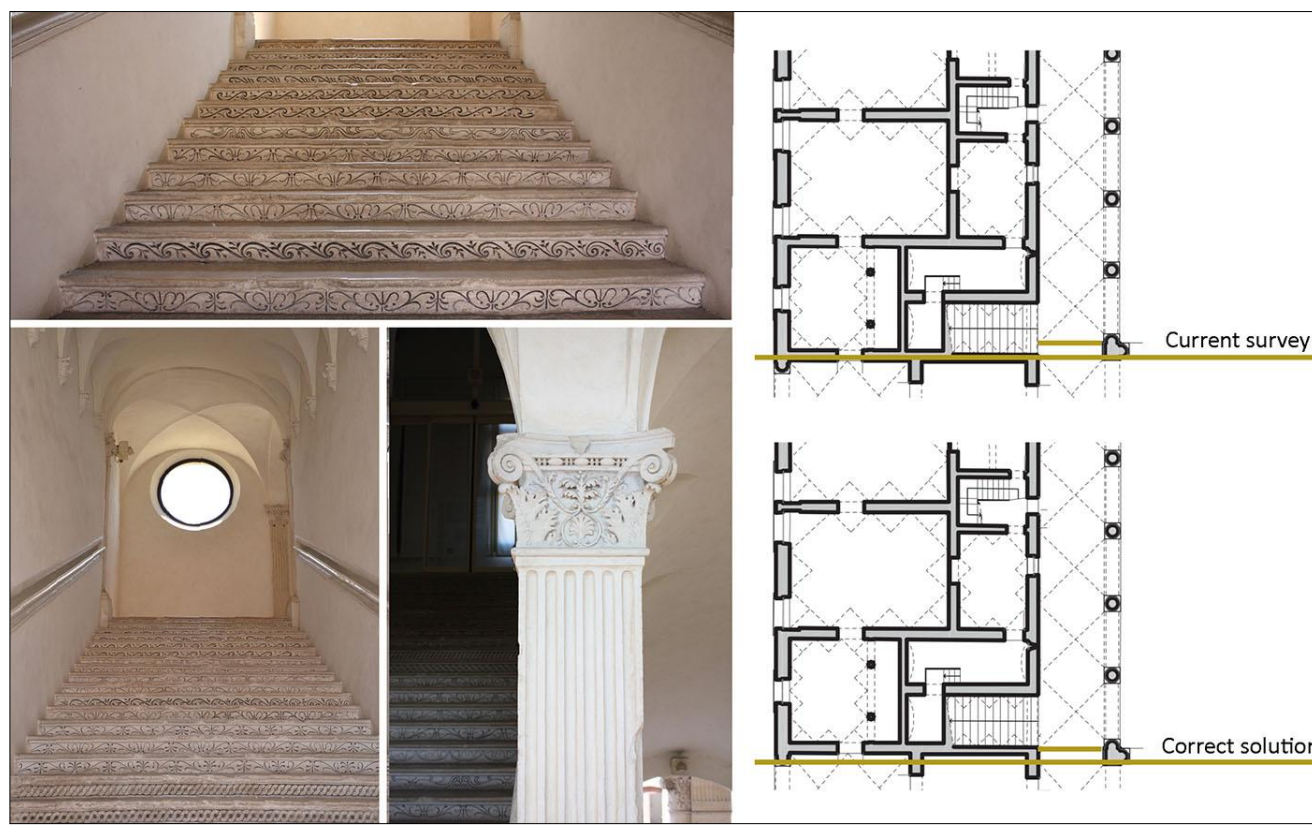

Figure 10. On the Left, Images of the Decorations of the Grand Stair; on the Right, the "Error" in the Architectural Composition between the Courtyard and the Grand Stair

Source: Survey and Photographs by the Author.

A second variation was made to the grand stair: the 1502 materials list speaks of 44 steps, with a perfectly proportioned ratio between riser and tread of 2:1. However, these measurements do not match what was actually built: the length of 
the steps corresponds only with a portion of the wall, which is later reduced on the inner side of the stair, as demonstrated by the survey. If we construct a stair with the dimensions and number of steps in the document from 1502, we would end up with a landing in correspondence with the room below, where we would find the two free columns on the ground floor on axis with the fluted pilasters of the stair. This would have created two perfectly coinciding rooms, one on the ground floor and one at the level of the landing (Figure 11).

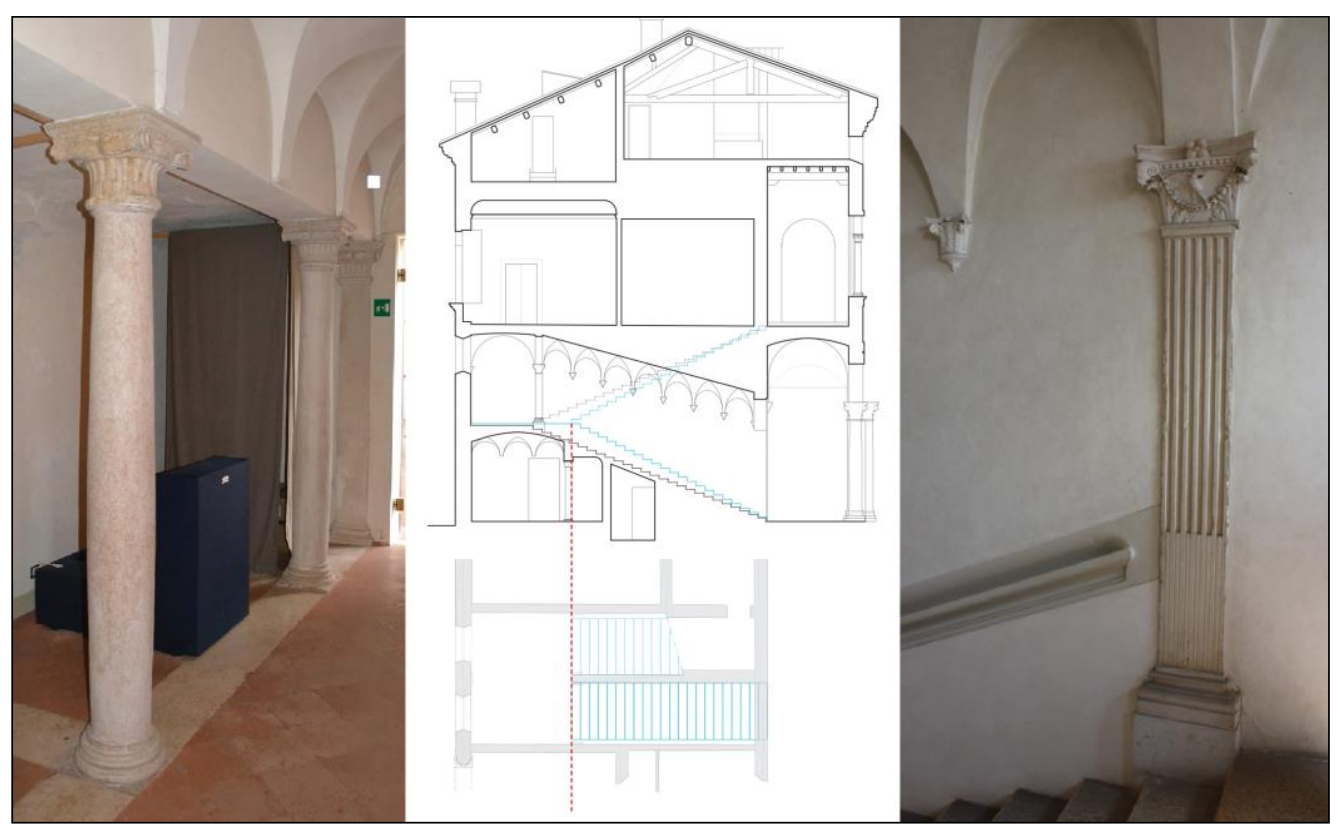

Figure 11. On the Left, the Column at the Ground Floor Level; on the Right, the Pilaster at the Landing of the Grand Stair Level. In the Center, a Cross Section Drawing Marks in Blue how the Grand Stair Could Have Been Built according to the Archive Documents

Source: Survey and Photographs by the author.

Until 1502 it would appear that there existed a project, however, during construction and with the changing of trades there seems to have been some difficulty in maintaining or building this original design. This would seem to explain the variations observed in plan.

Similar conditions can also be found in the elevations. Beginning with the elevation along Via Porta d'Amore, the brick rustication of the base course of the palace was left unfinished. This rustication, however, was started at the same time as the south block and thus by 1502 . The trabeation above the infilled crenellations of the west elevation, if it were ideally extended, would have arrived above the corner pilaster; all that remains of this element is a portion at the corner of the palace between Via Porta d'Amore and Via XX Settembre. The fluting of the corner pilaster begins at one third of the shaft; this datum makes it possible to infer the total height and understand the significance of the two elements that have remained incomplete. The desire to complete this trabeation is demonstrated in the document from 1502 (Figure 12). 


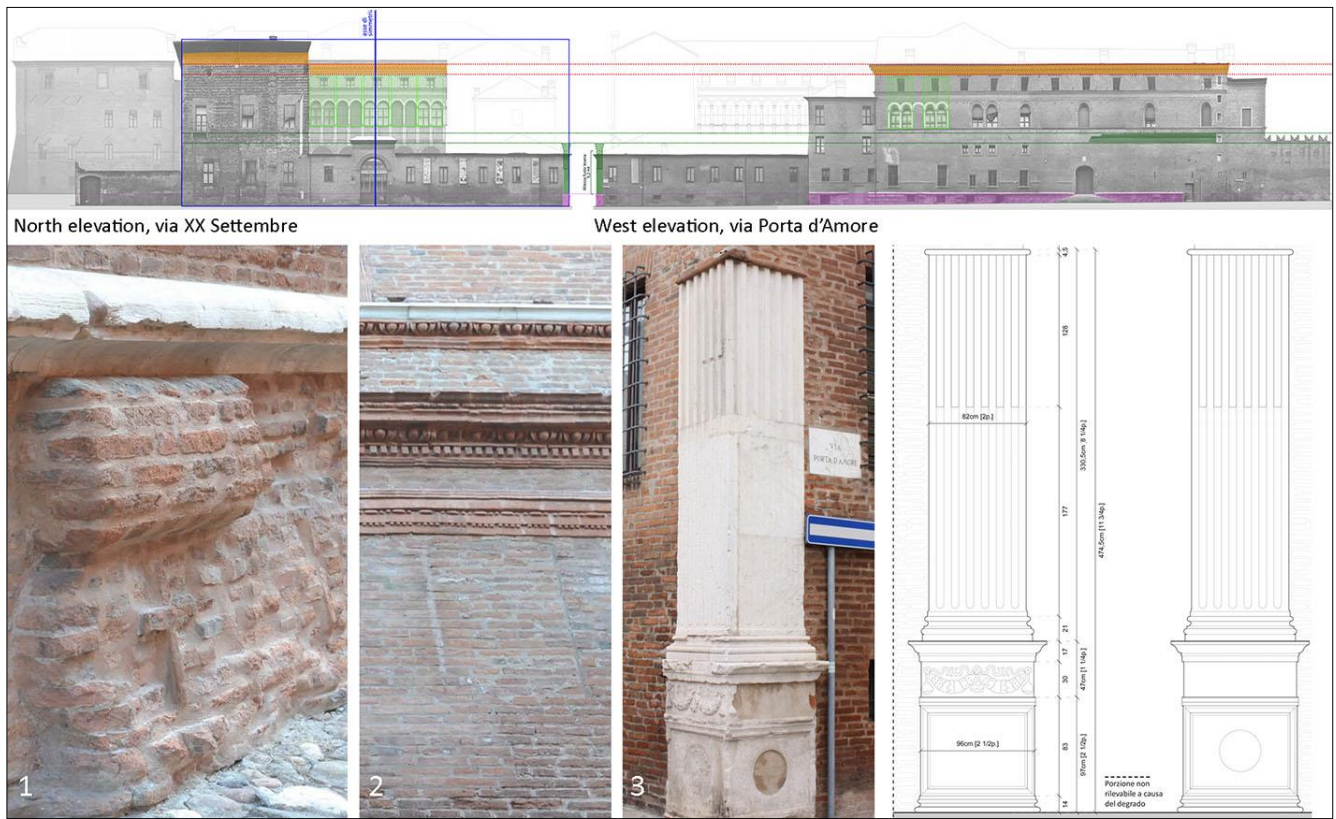

Figure 12. Unfinished Element of the Palace: The Brick Rustication of the Base (1), the Trabeation (2), the Corner Pilaster (3)

Source: Survey, Photomaps and Photographs by the Author.

The terminal cornice on the west elevation finds a formal and altimetric continuity in the cornice of the internal courtyard: proof of the existence of a unified project for these two parts of the palace (Figure 13).

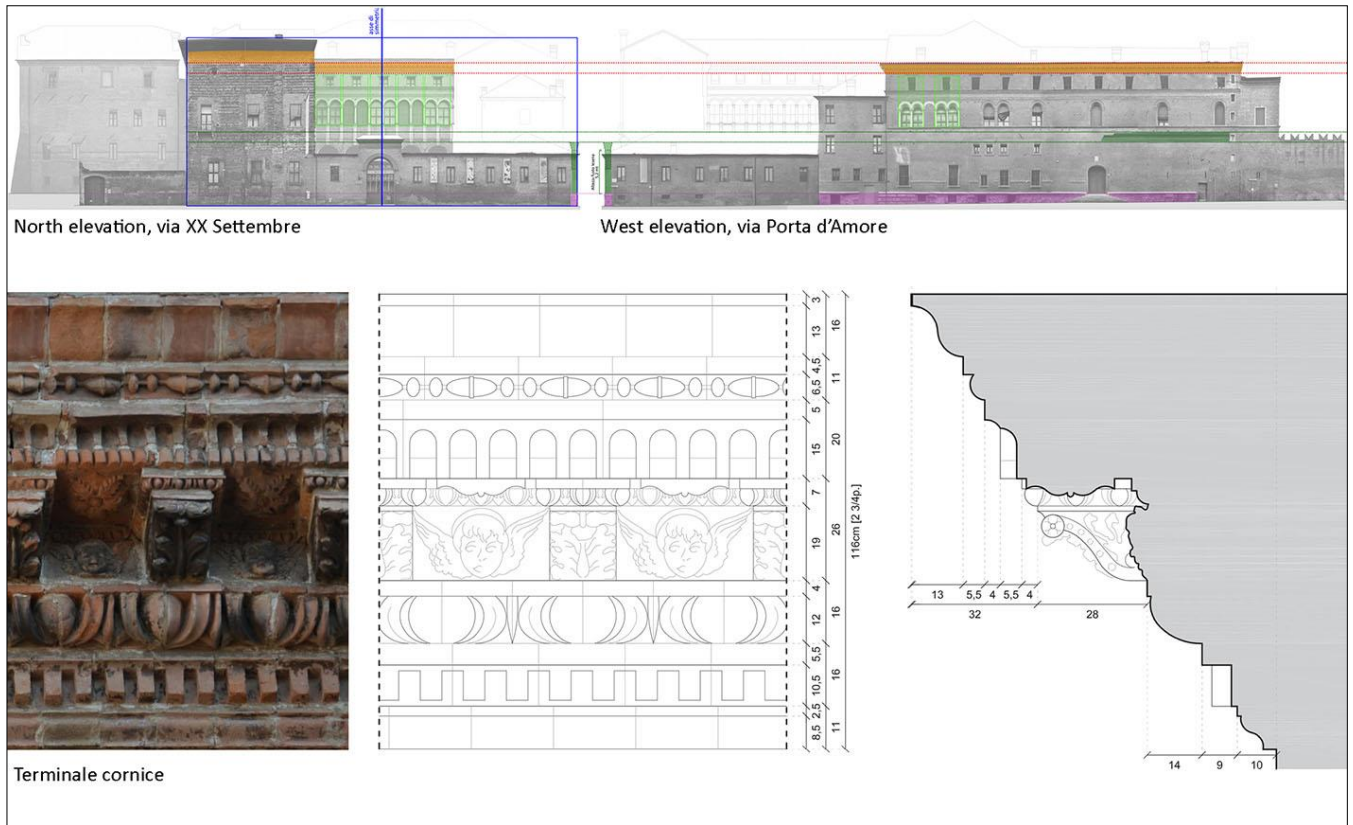

Figure 13. The Terminal Cornice on the West Elevation

Source: Survey, Photomaps and Photographs by the Author. 
There is a project that, in both plan and elevation, perhaps imagined a new language for Ferrara: as demonstrated in the design of the internal courtyard (Figure 14).

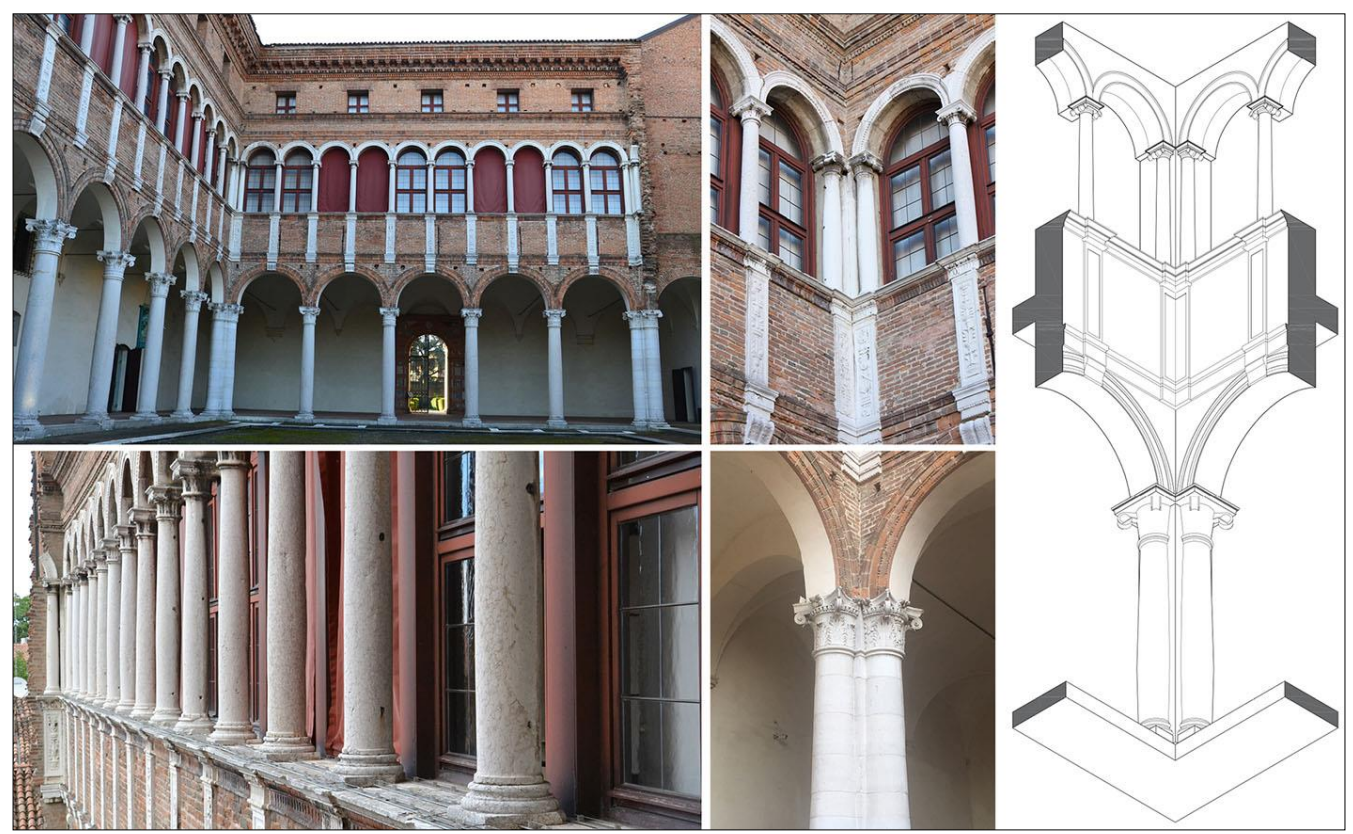

Figure 14. On the Left, Images of the Courtyard and, on the Right, an Axonometric Drawing of the Corner Solution

Source: Survey and Photographs by the author.

A courtyard whose design presents a proportion in elevation with an evident ratio of 2:1 between the first (12 Ferrarese feet) and second order (6 Ferrarese feet) and which respects the theoretical rule, ${ }^{46}$ first suggested by Vitruvius, where the upper order is equal to the lower order, after subtracting $1 / 4$ (Figure 15). The elevations correspond, instead, with a proportion of 1:1 on the south side and 2:3 (a fifth or diapente) on the east elevation. It appears that, where possible, despite the definition of measurements linked to pre-existing elements, there was a search for a proportionate harmony based on the architecture of "antiquity".

46. M. Vitruvio Pollione, De Architectura (Milano: Polifilo, 1997), 571; L. B. Alberti, L'Architettura (Milano: Il Polifilo, 1966), 808; F. Dg. Martini, Trattati di Architettura, Ingegneria e Arte Militare (Milano: Il Polifilo, 1967), 86; S. Serlio, Architettura Civile (Milano: Polifilo, 1994); Serlio, I Sette Libri dell'Architettura (Milano: Polifilo, 1987). 


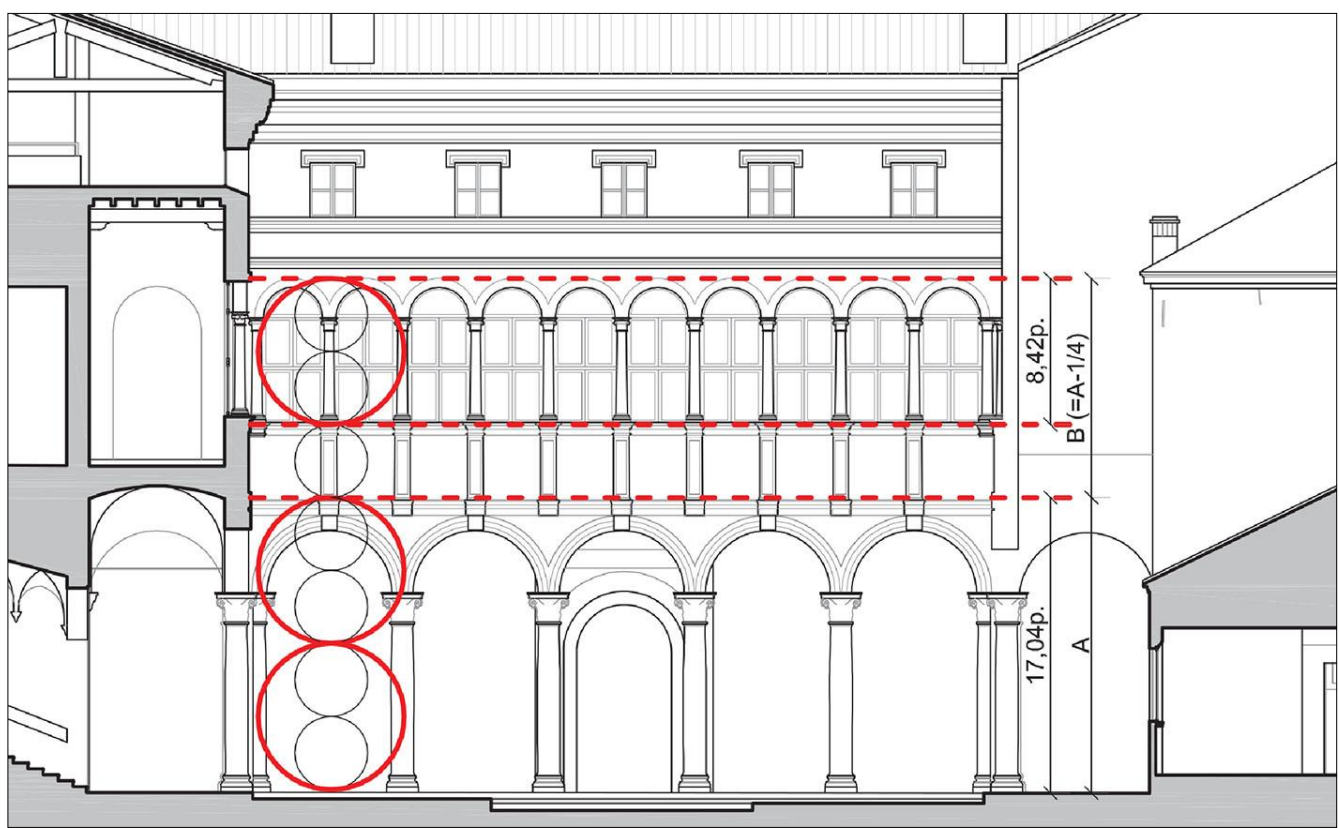

Figure 15. The Elevation Drawing of the Courtyard Shows the Respect of the Theoretical Rule First Suggested by Vitruvius

Source: Metrological and Proportional Survey by the Author.

\section{The History of the Palace's Restorations}

The analyses of Palazzo Costabili considered its restorations to be an integral part of the history of its construction. Of particular importance to this study was the analysis of documents relative to the restoration carried out between 1932 and 1935 , which led to the destruction of a series of walls in the second order of the central courtyard and the creation of a continuous open loggia. One of the results of this study is the entirely new understanding of the principle of construction of the second order, which defines the language of the most novel element of the palace's architecture.

We begin with two pieces of information: photographs taken prior to the restorations, in which the putlog holes in the walls of the infilled openings are evident and perfectly aligned.

The second element is the section: it is necessary to understand the misalignment and notable eccentricity of the upper columns respect to those below them. These columns could not have supported the weight of the roof, considering the important span of the main hall (Figure 16).

To understand what happened in Costabili's courtyard we need to look internally at the pentafora (mullioned window with five lights) illuminating the hall from Via Porta d'Amore (Figure 17). 


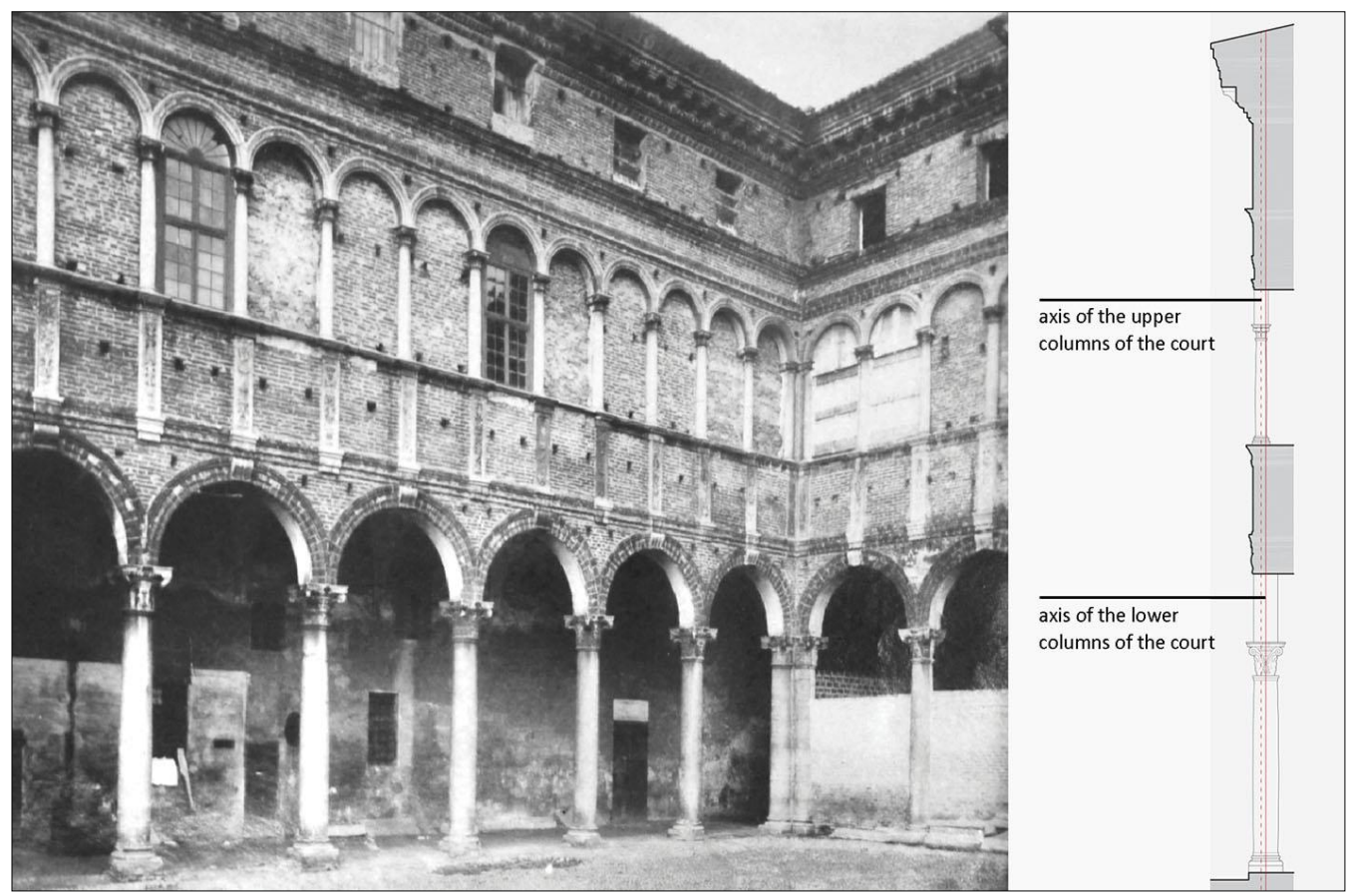

Figure 16. On the Left, a Historical Image of the Court before the Restoration; on the Right, the Cross Section Drawing of the Court with, in Evidence, the Eccentricity of the Upper Columns respected to those below them

Source: Image Preserved in the Archive of the Ministry of Culture in Ravenna; drawing by the Author.

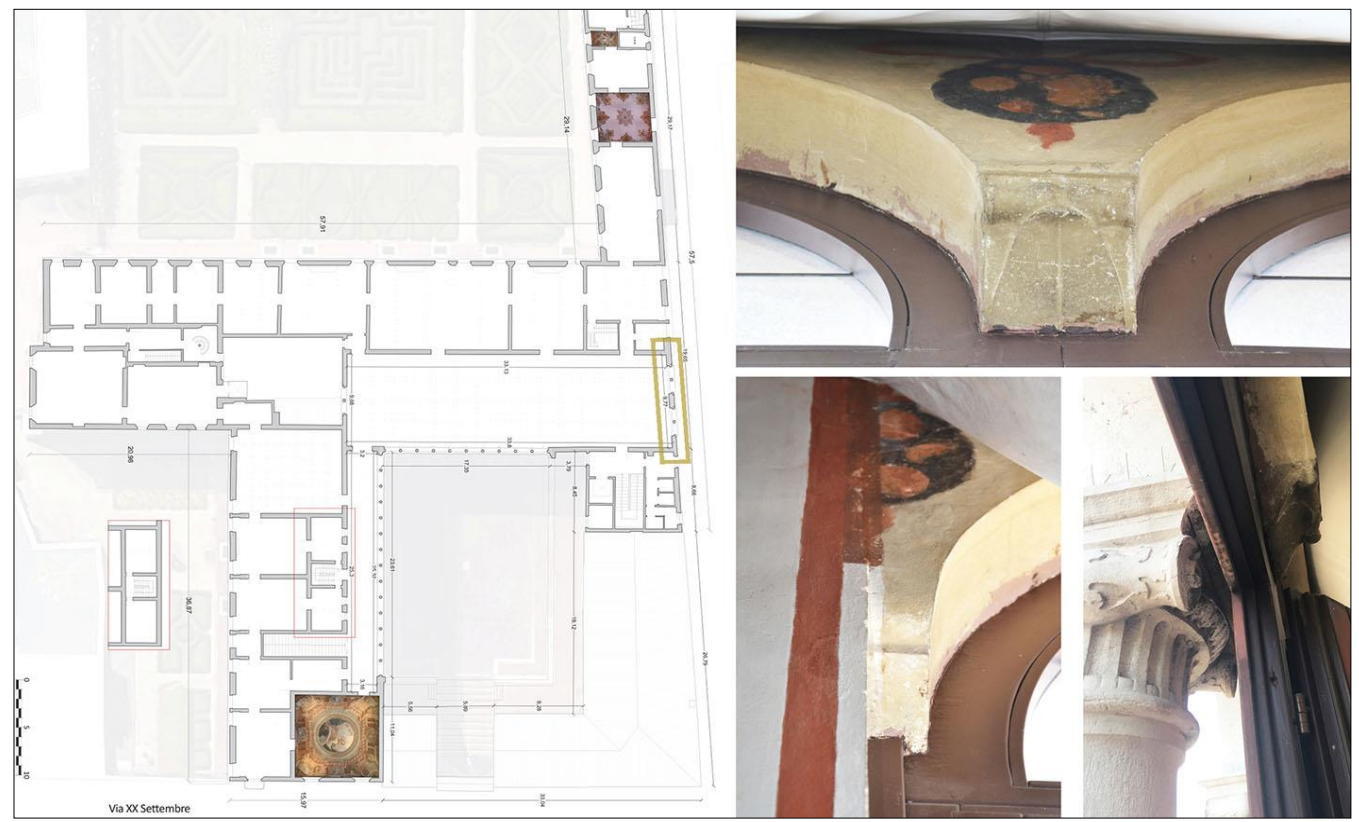

Figure 17. On the Left, the Pentafora on the First Floor (Identified with a Yellow Box); on the Right, the Decorations of the Pentafora

Source: Image Preserved in the Archive of the Ministry of Culture in Ravenna; Survey and Photographs by the Author. 
Here we can note the presence of brackets supporting hanging arches defining the bifora (lancet window), on the inside. There are decorative elements on the walls, such as a festoon of oranges and a garland with a bow that can also be found on the internal wall toward the courtyard. This unprecedented discovery was made possible by varying the saturation of a black and white photograph to expose these decorations (Figure 18).
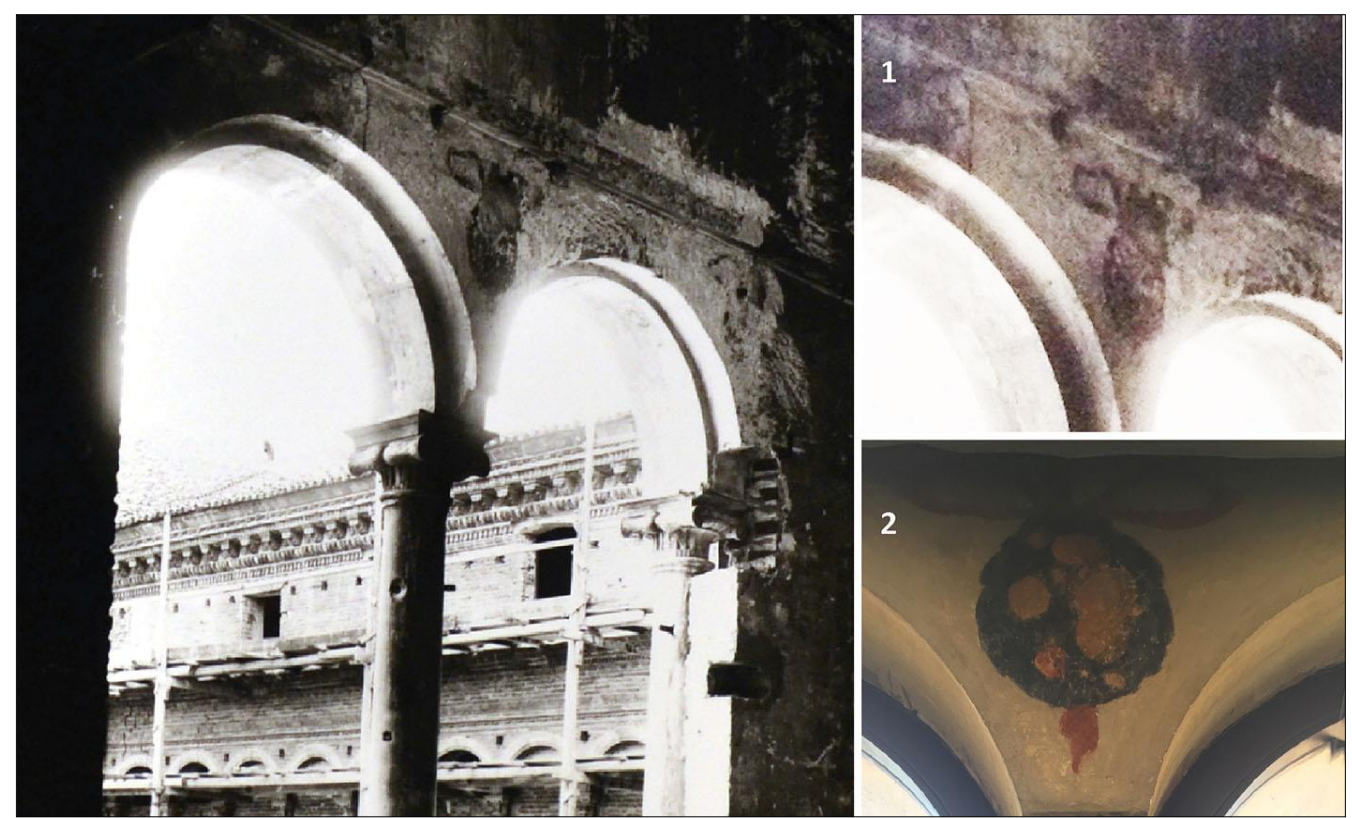

Figure 18. A Historical Photograph that Shows the Decorations Removed by the Restorations (1); These Decorations Were Identical to Those of the Pentafora as the Image on the Right Testifies (2)

Source: Image Preserved in the Archive of the Ministry of Culture in Ravenna; Survey and Photographs by the Author.

Historic photographs taken before the restorations show columns set into the walls, to the point that it is impossible to read one face of the capitals. This begs the question of why a request was made for fully sculpted columns (Figure 19). The study of the survey demonstrated that the idea of resting a marble diaphragm of columns and arches, which could be appreciated in their entirety, against a masonry structure, was possible only by creating a suitable internal bracket, as with the pentafora along Via Porta d'Amore, constructed prior to 1502, before the change of trades on site mentioned above. The comprehension of the architectural definition of the second order of the courtyard certainly represents a spatial invention for Ferrara at the end of the fifteenth century; an invention suitable to the client. While he plainly wished to set his roots in the most ancient part of the city, home to his family, and to use local tradesmen from his quarter, Antonio Costabili intended to create something unprecedented in Ferrara. 

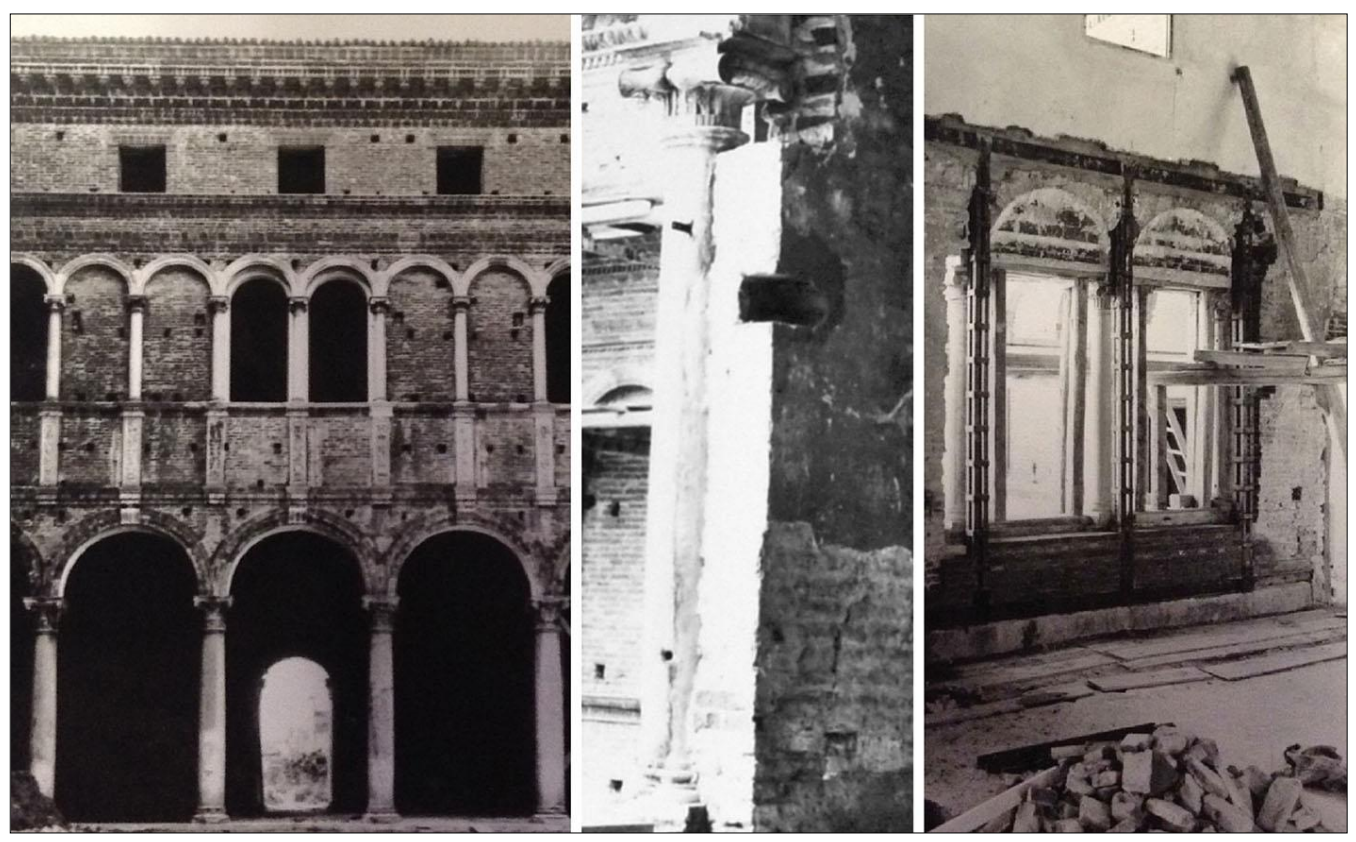

Figure 19. Historical Photographs before the Restorations; the Third Image Shows the Moment when the Restorations Destroyed the Walls behind the Columns Source: Images Preserved in the Archive of the Ministry of Culture in Ravenna.

\section{The Language in Use in Ferrara at the End of the Fifteenth Century}

Broadening our examination, from the detail to the more general events unfolding in Ferrara, and analysing different documents relative to other architectural projects from the late 1400s, the period of construction of Palazzo Costabili, appears to reveal a new language, a way of intending a building as a unified composition, whose constituent elements are part of a reciprocal relationship that responds to a ratio.

An analysis was made of archival documents relative to other projects under construction at the same time as Palazzo Costabili, for example Santa Maria in Vado and the new palaces of the Erculean Addition. New expressions contained in this material speak to a change methods of construction in Ferrara, of an "antique" approach to architecture: "ut dicitur a l'antiga". They also refer to a "ratio" 47 for proportioning columns; they also speak of a large cornice, commonly used at this time, for new buildings: "circumcirca (...) unam cornicem magnam secundum quod nunc communiter fit omnibus pallatiis de novo hedificatis"48 and "cingimenti de cornise" ${ }^{49}$ on the walls of the nave of the church.

A study of direct and indirect sources revealed a series of building details that demonstrate to what extent Palazzo Costabili can be said to belong to this latefifteenth century language for its reference to antiquity: from the layout of its plan to the proportioning of its courtyard.

47. Franceschini, Artisti a Ferrara in Età Umanistica e Rinascimentale. Testimonianze Archivistiche, 1997, 148.

48. Ivi, 277.

49. Ivi, 292. 
This reference to antiquity was part of humanist culture, permeated the court at Ferrara and inspired the design of Palazzo Costabili, not to mention Antonio Costabili himself.

In addition, we can also consider the particular cultural climate in which Costabili lived and the network of international relations he maintained. On the one hand Milan, the court of Ludovico Sforza where, at the end of the fifteenth century, we find the young Alfonso I d'Este and his brother the archbishop Ippolito d'Este, Antonio Costabili in the role of ambassador of Duke Ercole d'Este and, together with his brother Beltrando, as a member of il Moro's Secret Council. However, we must also consider relations with Rome in the early 1500s, where Alfonso travelled on many occasions and where, following his marriage to Lucrezia Borgia, his brother Ippolito d'Este was named archpriest at St. Peter's. Beltrando Costabili served as ambassador at the Papal Court until 1519.

Alfonso I d'Este is to Antonio Costabili as Ippolito d'Este was to Beltrando Costabili; this synthesis serves to clarify the international ties linking Ferrara with Milan and Rome. These ties are important to a proper understanding of the new language taking form in Ferrara during the period in question (Figure 20); important ties between different courts, with a consequent circulation of ideas and plans.

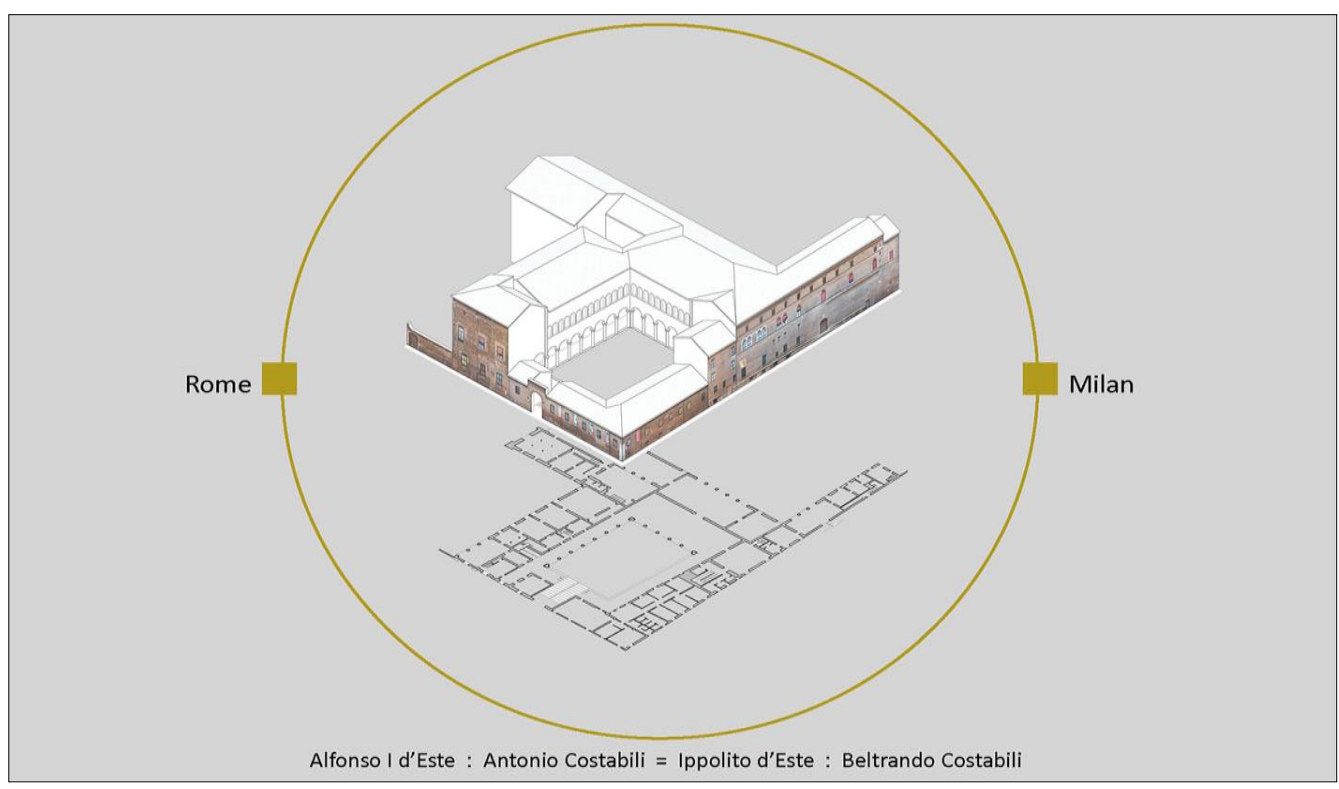

Figure 20. Palazzo Costabili of Ferrara must be related to the Architecture of the Renaissance at the Courts of Milan and Rome

Source: image created by the author.

\section{Conclusions}

This text began with a number of fixed points offered by the vast amount of literature describing the city of Ferrara as an important laboratory of fifteenth and sixteenth century culture. The chronological limits within which we can certainly place the exceptional history of Ferrara span the duration of the Duchy of Ferrara 
(1471) to Devolution (1598), when the city became a province at the margins of the Papal State. There is no doubt that this period witnessed years of florid construction, evidence of broad diplomatic policies with the objective of earning Ferrara an important role in a system of political equilibriums, hard won in the wake of the Peace of Lodi in 1454.

With Ercole I d'Este (1471-1505) and his son Alfonso I (1505-1534), the scale of the interventions realised and planned assumed a relevance that exceeded the importance of purely local questions.

Literary sources have explored and attributed to enlightened clients - the dukes - the capacity to imagine the capital of a Duchy whose cultural importance would expand it beyond its city walls. Numerous buildings were constructed in a very short time. We need only consider the new works tied to the Erculean Addition after 1492, with its noble palaces, churches and a new public square. New buildings were also erected inside the medieval city, such as Palazzo Costabili, and pre-existing churches were expanded, for example San Francesco, Santa Maria in Vado and the Cathedral.

However, if the role of clients, embodied by the D'Este dukes Ercole and Alfonso, has been largely clarified, what contribution was made by so many other figures involved in this process of construction: artisans, entrepreneurs, superintendents or even architects?

This question can be extended to any construction commissioned by the dukes or private citizens.

The research presented begins with a precise methodological assumption: that any general study and any interpretative synthesis cannot avoid an in-depth investigation of specific events, through a rigours ascertainment of facts and a consequent analytical reconstruction of the building process, as stated in the premise.

The particular history of the erection of Palazzo Costabili was reconstructed by overlapping the results of indirect analyses with a specific interpretation of any consideration arising from direct experience. This necessary philological reconstruction was followed by an interpretation of the unresolved parts of the building: from a reading of the plan that revealed previously unidentified preexisting elements, to the comprehension of the small courtyard in the south-east portion of the palace, to the definition of the second order of the courtyard with its alternation of solids and voids, to the proportioning of the elevations of the courtyard to the evident errors or changes made during construction, to the grand stair, to the misalignment between the stair and the corner column to the unfinished elevations. The result of this investigation led to a hypothesis of the phases of the palace's construction and revealed the particular moment of a change in tradesmen in 1502.

The interpretation of the architectural language used in the design of the palace, with a ratio imagined and realised based on precise intentions, was followed by an attempt to place its construction within the architectural culture of its time in order to identify eventual affinities with a growing interest in antiquity.

The analysis of documents relative to coeval projects appears to describe, precisely at the end of the fifteenth century, as Palazzo Costabili was under 
construction, the emergence of a new architectural language that differed from that of the fourteenth and fifteenth centuries; a way of intending a building as a unified composition, whose constituent elements are part of a reciprocal relationship that responds to a ratio.

The question of attribution was raised only at the end of this process of study. It was approached as the conclusion of a rigorous historic reading of this work of architecture, centred on the study of drawings and construction.

Biagio Rossetti, considered by many critics, and in particular Zevi, ${ }^{50}$ to be the architect of Palazzo Costabili, appears incompatible with its refined architecture.

The necessary humanist culture, innate to the informed design of Palazzo Costabili, was clearly possessed by Antonio Costabili. We know that he enjoyed a particular network of personal and cultural relations with Milan in the late-1400s and Rome at the beginning of the 1500s, with Alfonso I and Ippolito d'Este and, in particular, with his own brother Beltrando.

The palace can be said to resemble a choral realisation of a precise project, in which the client's intentions take form through a series of interventions carried out by teams of tradesmen, a succession of masons in only a few years, stoneworkers, carpenters and painters, all coordinated by a Ducal engineer or expert mason, such as Tristano. Yet, its architecture is decided by the skill and desire of a humanist client, in this case Antonio Costabili.

Only Costabili's Studia humanitatis, an education described in the first chapter, allows us to understand the proportions between the different architectural parts and to justify the cultured language employed at Palazzo Costabili, a true example of a new art of building that developed in Ferrara between the latefifteenth-early sixteenth century.

\section{Bibliography}

Agnelli, G. Il Palazzo di Lodovico il Moro in Ferrara [The Palace of Lodovico il Moro in Ferrara.] Ferrara: Zuffi, 1902.

Alberti, L. B. L'Architettura [Architecture.] Milano: Il Polifilo, 1966, 808.

Alfieri, N. Il Palazzo Detto di Ludovico il Moro [The Palace Known as Ludovico il Moro.] Rovigo: STER, 1955.

Avventi, F. Il Servitore di Piazza: Guida per Ferrara [The Square Servant: Guide for Ferrara.] Ferrara: Pomatelli, 1883, 153-155.

Baretta, S. "Il Palazzo di Ludovico il Moro." [The Palace of Ludovico il Moro.] In F. D. Bollettino della Ferrariae Decus. Ferrara: Este Edition, 1998, 7-22.

Boari, A. "Bramante, Rossetti e il Palazzo d Ludovico il Moro Bramante" [Rossetti and the Palace of Ludovico il Moro.] In Gazzetta Ferrarese. Ferrara: Officina della Gazzetta, 1914.

Bruschi, A. Introduzione alla Storia dell'Architettura. Considerazioni sul Metodo e sulla Storia degli Studi [Introduction to the History of Architecture. Considerations on the Method and History of Studies.] Città di Castello: Mondadori Università. 2009.

50. Zevi, Biagio Rossetti Architetto Ferrarese il Primo Urbanista Moderno Europeo, 1960, 320-324 
Burckhardt, J. Storia del Rinascimento in Italia [History of the Renaissance in Italy.] Torino: N. Aragno, 2006, 324.

Calcagnini, C. Opera Aliquot. Basilea, 1544, 436.

Cittadella, N. Indice Manuale delle Cose Più Rimarcabili in Pittura, Scultura, Architettura della Città e Borhi di Ferrara [Manual Index of the Most Remarkable Things in Painting, Sculpture, Architecture of the City and Boros of Ferrara.] Ferrara, 1844, 6769.

Calzecchi Onesti, C. "Il Palazzo detto di Lodovico il Moro, Cenni Storici e Critici e Relazione sui Restauri" [The Palace Known as Lodovico il Moro, Historical and Critical Notes and Report on Restorations.] In The Spina Museum in Ferrara. Edited by S. Aurigemma. Ferrara: Municipality of Ferrara, 1936.

Di Francesco, C. "Palazzo di Ludovico il Moro (Note Storiche)" [The Palace of Ludovico il Moro (Historical Notes).] In Giardini e Palazzi Rinascimentali di Ferrara. Sviluppo Urbanistico Moderno. Ferrara: Atti del Corso di Aggiornamento, 1996, 194-199.

Fedozzi, I. and B. Guelfi. "Nuovi Documenti e Ipotesi di Lavoro su un Committente Ferrarese nell'Età di Alfonso I: il Conte Costabili" [New Documents and Working Hypotheses on a Client from Ferrara in the Age of Alfonso I: Count Costabili.] In Il Camerino delle pitture di Alfonso. Padova: Bertoncello Arti Grafiche, 2007, 65-76.

Franceschini, A. Artisti a Ferrara in Età Umanistica e Rinascimentale. Testimonianze Archivistiche [Artists in Ferrara in the Humanistic and Renaissance Age. Archive Testimonies.] Ferrara-Roma: Gabriele Corbo Editore, 1997.

Frizzi, A. Guida del Forestiere per la Città di Ferrara del Dott [Guide of the Stranger for the City of Ferrara.] Ferrara, 1787, 135-136.

Giovannoni, G. "Ferrara. The Palace of Ludovico il Moro" [Ferrara. Il Palazzo di Ludovico il Moro.] In Rassegna di Architettura, no. 8-9. Milano: Graphic Institute, 1936, XXIV-XXVI.

Guarini, M. A. Compendio Historico dell'Origine, Accrescimento e Prerogative delle Chiese, e Luoghi pii della Città e Diocesi di Ferrara [Historical Overview of the Origin, Growth and Prerogatives of Churches, and Pious Places in the City and Diocese of Ferrara.] Ferrara, 1621, 294-295.

Marcianò, A. F. L'Età di Biagio Rossetti. Rinascimenti di Casa d'Este [The Age of Biagio Rossetti. Renaissance of the House of Este.] Ferrara-Roma: Gabriele Corbo Editore, 1991, 115-126.

Martini, F. dG. Trattati di Architettura, Ingegneria e Arte Militare [Treaties of Architecture, Engineering and Military Art.] Milano: Il Polifilo, 1967, 86.

Nardelli, C. and M. Tassotti. L'Addizione di Borso: Analisi dell'Edilizia Storica sull'Asse Quattrocentesco di via Ghiara: Individuazione del Limite Fisiologico di Trasformazione degli Organismi Edilizi Finalizzata alla Loro Conservazione [The Addition of Borso: Analysis of Historical Buildings on the Fifteenth-Century Axis of Via Ghiara: Identification of the Physiological Limit of Transformation of Building Bodies Aimed at their Conservation.] Master Degree Thesis. University of Ferrara, 2009.

Padovani, G. "Biagio Rossetti e il Palazzo di Antonio Costabili" [Biagio Rossetti and the Palace of Antonio Costabili.] In Corriere Padano. Ferrara: Soc. An. Emiliana, 1930. . Architetti Ferraresi [Ferrara Architects.] Rovigo: STER, 1955, 82.

Pattanaro, A. "Garafolo e Cesariano in Palazzo Costabili a Ferrara" [Garafolo and Cesariano in the Costabili Palace in Ferrara.] In Prospettiva. Firenze: Centro Di, 1994, 97-110.

. "Il Restauro di un Importante Affresco Rinascimentale Apre Nuove Prospettive Storiche" [The Restoration of an Important Renaissance Fresco Opens up New 
Historical Perspectives.] In Ferrara voci di una città. Ferrara: Cassa di Risparmio di Ferrara Foundation, 2009, 39-43.

Petrucci, F. “Antonio Costabili." In Biographical Dictionary of Italians. Roma: Institute of the Italian Encyclopedia, 1984, 257-260.

Piconi Aprato, G. "Il Palazzo Detto di Lodovico il Moro in Ferrara" [The Palace Known of Lodovico il Moro in Ferrara.] In Ferrarese Museums, Annual Bulletin. Firenze: Centro Di, 1972, 117-128.

Reggiani, G. I Portali di Ferrara nell'Arte [The portals of Ferrara in art.] Ferrara: Tipografia Taddei-Soati, 1907, 102-103.

. "Bramante, Rossetti e il Palazzo d Ludovico il Moro" [Bramante, Rossetti and the Palace of Ludovico il Moro.] In Gazzetta Ferrarese. Ferrara: Officina della Gazzetta, 11 Giugno 1914.

Righini, E. Quel che Resta di Ferrara Antica [What Remains of Ancient Ferrara.] Ferrara: Estense Libro, 1911, 55-98.

. "Bramante, Rossetti e il Palazzo d Ludovico il Moro" [Bramante, Rossetti and the the Palace of Ludovico il Moro.] In Gazzetta Ferrarese. Ferrara: Officina della Gazzetta, 1914.

Sambin de Norcen, M. T. "Osservazioni sui Palazzi (1490-1503)" [Observations on the Buildings (1490-1503).] In Grande così Quanto Forse Ignorato: Omaggio a Biagio Rossetti. Ferrara: Grafiche Turato Edizioni, 2018, 49-66.

Scalabrini, G. A. Momorie Istoriche delle Chiese di Ferrara e de' Borghi [Historical Scenes from the Churches of Ferrara.] Ferrara, 1773, 288-289.

Serlio, S. I Sette Libri dell'Architettura [The Seven Books of Architecture.] Milano: Polifilo, 1987. . Architettura Civile [Civil Architecture.] Milano: Polifilo, 1994.

Varese, R. "Il Palazzo di Costabili (Detto di Ludovico il Moro)" [The Palace of Costabili (Known of Ludovico il Moro).] In Spina. Museo Archeologico Nazionale di Ferrara. Bologna: Calderini, I-XXV.

Vitruvio Pollione, M. De Architectura. Milano: Polifilo, 1997, 571.

Zaccarini, D. "Ferrara. Palazzo di Ludovico il Moro" [The Palace of Ludovico il Moro.] In Architettura e arti decorative Ferrara. Milano-Roma: Bestetti and Tumminelli, 1922, 304-305.

Zevi, B. Biagio Rossetti Architetto Ferrarese il Primo Urbanista Moderno Europeo [Biagio Rossetti, Ferrara Architect, the First European Modern Urban Planner.] Torino: Einaudi, 1960, 320-324. 